\title{
DIGITALCOMMONS
}

@WAYNESTATE-

Wayne State University

Law Faculty Research Publications

Law School

$1-1-1981$

\section{Retrial after a Hung Jury: The Double Jeopardy Problem}

Janet E. Findlater

Wayne State University, j.findlater@wayne.edu

\section{Recommended Citation}

Janet E. Findlater, Retrial after a Hung Jury: The Double Jeopardy Problem, 129 U. Pa. L. Rev. 701 (1981). doi: 10.2307/3311743

Available at: http://digitalcommons.wayne.edu/lawfrp/1

This Article is brought to you for free and open access by the Law School at DigitalCommons@WayneState. It has been accepted for inclusion in Law

Faculty Research Publications by an authorized administrator of DigitalCommons@WayneState. 


\title{
RETRIAL AFTER A HUNG JURY: THE DOUBLE JEOPARDY PROBLEM
}

\author{
JANET E. FindLATER †
}

For nearly a century, the United States Supreme Court has held that the double jeopardy clause of the fifth amendment ${ }^{1}$ does not bar retrial following a hung jury. ${ }^{2}$ It has done so consistently, without discussion of the issue, by peremptory citation to the 1824 decision of United States $v$. Perez. ${ }^{3}$ In 1978, however, the Court acknowledged that Perez need not be read as a double jeopardy case, ${ }^{4}$ but summarily dismissed the possibility that Perez was decided on quite different grounds as "of academic interest only." 5

The implication is clear-the Court will continue to adhere to the Perez rule despite the fact that Perez was not a constitutional case. $^{\circ}$ It is the thesis of this Article that in so doing the Court is in error. ${ }^{7}$ Whatever the validity in 1824 of the Perez result, the

† Associate Professor of Law, Wayne State University. A.B. 1970, Smith College; J.D. 1974, University of Michigan.

The author wishes to express her gratitude to Kathryn J. Humphrey, Class of 1980, Wayne State University Law School, for her invaluable research assistance on this Article.

1 The fifth amendment to the United States Constitution provides in part: "[N]or shall any person be subject for the same offense to be twice put in jeopardy" of life or limb." U.S. ConsT. amend. V. The Supreme Court has held that the double jeopardy clause of the fifth amendment applies to the states through the fourteenth amendment. Benton v. Maryland, 395 U.S. 784, 794 (1969). See also Crist v. Bretz, 437 U.S. 28, 32 (1978). Additionally, all but five states (Connecticut, Maryland, Massachusetts, North Carolina and Vermont) have double jeopardy provisions in their constitutions. See ALI, Administramion of the Crmmanal Law: Double Jeopardy $\$ 6$, comment at 61-65 (Off. Draft, 1935). This Article will focus on double jeopardy as expressed in the fifth amendment.

2 See Keerl v. Montana, 213 U.S. 135 (1909); Dreyer v. Illinois, 187 U.S. 71 (1902); Logan v. United States, 144 U.S. 263 (1892).

322 U.S. (9 Wheat.) 579 (1824).

4 "In fact, a close reading of the short opinion in that case could support the view that the Court was not purporting to decide a constitutional question, but simply settling a problem arising in the administration of federal criminal justice." Crist v. Bretz, 437 U.S. 28, 34 n.10 (1978).

5 "But to cast such a new light on Perez at this late date would be of academic interest only." Id.

'The Court, of course, implicitly decided a constitutional question in Perez: it concluded that the double jeopardy clause did not apply to the hung jury case because, as the Court then interpreted that clause, jeopardy did not attach until a verdict was rendered. See text accompanying notes 13-18 infra. But, given the Court's premise that jeopardy was not implicated before verdict, the ultimate question for decision in Perez-whether retrial was permissible following a hung jury-was not a double jeopardy question.

7 The point is of no small import. It is estimated that approximately five percent of the cases that go to trial end in a hung jury. H. KALVEN \& H. ZeISEL, The American JuRy $57 \&$ n.2 (1966). 
rule that retrial following a hung jury does not run afoul of the Constitution is today, with all the respect due its years, simply dead wrong.

The rule is not mandated by the Constitution. It is inconsistent with double jeopardy policy that has become established doctrine in the 150 years since Perez was decided. But due to the misconstruction of Perez, the double jeopardy question implicated in the hung jury case was assumed to have long been resolved. Consequently, the hung jury issue, disposed of by wooden application of Perez, has been insulated from developments in the law of double jeopardy. It is past time to end this treatment of historical accident as immutable constitutional doctrine and to evaluate the hung jury case in light of current double jeopardy policy. Such an evaluation points strongly to the conclusion that retrial following a hung jury is constitutionally impermissible.

Part I of this Article demonstrates that Perez has been misread for nearly a century. Perez was not a double jeopardy case; instead, it involved a common law rule regarding the authority of the trial court to discharge a jury before verdict. Part II first examines the significance of this error and the resultant elevation of the Perez "manifest necessity" test to constitutional status. In particular, it criticizes using the presence or absence of manifest necessity to terminate the first trial to determine whether the defendant can be forced to undergo a second trial. The retrial question should be answered according to double jeopardy policy, not a common law rule of trial procedure. Part II then identifies current double jeopardy policy as found in recent Supreme Court opinions. Part III evaluates the hung jury issue in light of this policy and concludes that retrial following a hung jury is unconstitutional.

\section{Perez Misread: Constitutional Jeopardy, Common Law JEOpardy, AND the No-Discharge Rule}

Since United States $v$. Perez, ${ }^{8}$ the Supreme Court has considered three cases squarely presenting the question whether retrial following a hung jury violates the double jeopardy clause. ${ }^{9}$ All were decided on the authority of Perez without analysis of either the issue or the controlling case. ${ }^{10}$ Additionally, the Court in dictum has

822 U.S. ( 9 Wheat.) 579 (1824).

9 Keerl v. Montana, 213 U.S. 135 (1909); Dreyer v. Illinois, 187 U.S. 71 (1902); Logan v. United States, 144 U.S. 263 (1891).

10 For example, in Keerl the Court made clear that it considered the matter of retrial following a hung jury closed: "On the merits, there is little room for con- 
interpreted Perez as a case holding that retrial following a hung jury does not constitute double jeopardy. ${ }^{11}$

Although the question in Perez was indeed whether a defendant could be retried following a hung jury, ${ }^{12}$ nowhere in the unanimous opinion authored by Justice Story is either double jeopardy or the fifth amendment mentioned. This failure to refer to the Constitution was not inadvertent. In 1824 , the hung jury question did not implicate the double jeopardy clause of the fifth amendment. At that time, the Court adhered to the English common law view that jeopardy does not attach until a verdict is rendered. ${ }^{13}$ Because a

troversy. In ... [Perez], this court passed upon the question arising under the Fifth Amendment .... This has been the settled law of the Federal courts ever since that time." 213 U.S. at 137-38 (citations omitted). See also Dreyer v. Illinois, 187 U.S. at 85-87; Logan v. United States, 144 U.S. at 297-98.

11 E.g., Arizona v. Washington, 434 U.S. 497, 506 (1978); United States v. Martin Linen Supply Co., 430 U.S. 564,571 (1977); United States v. Sanford, 429 U.S. 14, 16 (1976); Illinois v. Somerville, 410 U.S. 458, 461-62 (1973); United States v. Jorn, 400 U.S. 470, 480-81 (1971); Downum v. United States, 372 U.S. 734, 735-36 (1963); Gori v. United States, 367 U.S. 364, 368-69 (1961); Wade v. Hunter, 336 U.S. $684,689-90$ (1949).

12 The Perez Court held:

We think, that in all cases of this nature, the law has invested courts of justice with the authority to discharge a jury from giving any verdict, whenever, in their opinion, taking all the circumstances into consideration, there is a manifest necessity for the act, or the ends of public justice would be otherwise defeated.

22 U.S. (9 Wheat.) at 580. The Court warned, however, that this authority to abort a trial "ought to be used with the greatest caution, under urgent circumstances, and for very plain and obvious causes." Id.

13 See generally M. Hate, Pleas of the Crown 205-10 (London 1678). The rule in England today is still that jeopardy attaches with the verdict. II Hatsbury's Laws of England, Crminal Law, Evmence aNd Procedure $\{242$ (4th ed. 1976).

A number of state courts initially took the same position. Stone v. People, 3 IIl. (2 Scam.) 326, 337 (1840); O'Brian v. Commonwealth, $69 \mathrm{Ky}$. (6 Bush) 563, 570 (1870); Commonwealth v. Olds, $15 \mathrm{Ky}$. (5 Litt.) 137, 140 (1824) (state constitution construed); Hoffman v. State, 20 Md. 425, 434 (1863); Commonwealth v. Purchase, 19 Mass. (2 Pick.) 521, 526 (1824); Price v. State, 36 Miss. 531, 544 (1858); State v. Moor, I Miss. (I Walker) 134, 139 (I823); People v. Goodwin, 18 Johns. 187, 206 (N.Y. Sup. Ct. 1820); accord, United States v. Bigelow, 14 D.C. (3 Mackey) 393, 405 (1884). Contra, In re Spier, 12 N.C. (1 Dev.) 491, 494-95 (1828); State v. Garrigues, 2 N.C. (1 Hayw.) 241, 242 (1795); Commonwealth v. Clue, 3 Rawle 498, 501 (Pa. 1831); Commonwealth v. Cook, 6 Serg. \& Rawl. 577, 586 (Pa. 1822); State v. M'Kee, 17 S.C.L. (I Bail.) 651, 654-55 (1830); Williams v. Commonwealth, 43 Va. (2 Gratt.) 567, 570-71 (1845). Of those jurisdictions initially following the English view, some changed their position upon reconsideration of the issue. See O'Brian v. Commonwealth, $72 \mathrm{Ky}$. (9 Bush) 333, 342-43 (1872); Teat v. State, 53 Miss. 439, 453-55 (1876).

In 1935, against the overwhelming weight of authority, the American Law Institute recommended adoption of the rule that jeopardy attach with the verdict. The AII draft provides that the "fact that a person has been put on trial for an offense is not a bar to a subsequent trial of such person for the same offense unless on the former trial he was acquitted or convicted." ALI, ADMINISTRATION OF THE Cnmmal Law: Double Jeopardy $\$ 6$ (Off. Draft, 1935). 
non-unanimous jury returns no verdict, jeopardy did not attach, and the fifth amendment thus had no bearing on whether the defendant could be retried.

That Justice Story was of this view can be inferred from his statement in Perez that "the facts constitute no legal bar to a future trial. The prisoner has not been convicted or acquitted, and may again be put upon his defence." 14 Ten years later, in United States v. Gibert, ${ }^{15}$ Justice Story confirmed that Perez did not involve application of the double jeopardy clause: "Upon that occasion the court did not go into any exposition of the clause in the constitution now under consideration; but simply stated that in the case of Perez, the prisoner had not been convicted or acquitted, and therefore might again be put upon his defence." 16 Similarly, Justice

The Supreme Court has rejected this position, adhering instead to the view that jeopardy attaches when the jury is impaneled and sworn. This rule has been raised to constitutional status and made applicable to the states. Crist v. Bretz, 437 U.S. 28 (1978). See notes 34 \& 35 infra.

1422 U.S. ( 9 Wheat.) at 579.

Similarly, see United States v. Haskell, 25 F. Cas. 207 (C.C.E.D. Pa. 1823) (No. 15,321). Justice Washington, sitting on circuit, held that a juror's insanity justified discharge of the jury before verdict and that such discharge did not bar retrial. Washington explicitly refused to apply the fifth amendment because "the jeopardy spoken of in this [amendment] can be interpreted to mean nothing short of the acquittal or conviction of the prisoner, and the judgment of the court thereupon. This was the meaning affixed to the expression by the common law ... Id. 212.

Compare the view of the Supreme Court of Pennsylvania in 1822: "There is a wide difference between a verdict given, and the jeopardy of a verdict. Hazard, peril, danger, jeopardy of a verdict, cannot mean a verdict given." Commonwealth v. Cook, 6 Serg. \& Rawl. 577, 596 (Pa. 1822) (Duncan, J., concurring).

1525 F. Cas. 1287 (C.C.D. Mass. 1834) (No. 15,204).

16 Id. 1300.

Defendants in Gibert were convicted of piracy and sentenced to death. They petitioned the Court for a new trial on the grounds of newly discovered evidence and legal error at trial. Because jeopardy attached when the original verdict was entered, Justice Story reasoned that a new trial would twice put each defendant in jeopardy in violation of his fifth amendment right because it would result in entry of a second verdict. Unhappily for the defendants in Gibert, Justice Storyconvinced that protection of their fifth amendment right, literally construed, was worth more than their necks-ordered them hanged. To understate: quaere.

Justice Story's literal interpretation of the double jeopardy clause has been uniformly rejected. In the third edition of Story's Commentaries, Gibert is quoted at length in a footnote (the Gibert quote having been added in the second edition), but the following editorial comment was added by Judge Edmund $H$. Bennett: "But this opinion of Judge Story never found favor in other tribunals, and the contrary doctrine may be considered as generally established. See Ball v. The Commonwealth, 8 Leigh, 726; Weinzorpflin v. The State, 7 Blackford, 166; United States v. Keen, I McLean, 429; 3 McLean, 573; United States v. Harding, 1 Wallace Jr.; 2 Lead. Crim. Cases, 492, where all authorities are collected." $2 \mathrm{~J}$. Story, Commentardes on the Constitution \$1787 n.3 (3d ed. E. Bennett 1858) (Ist ed. Boston 1833). In the fourth edition, edited by Justice Cooley, all references to Gibert were removed. 2 J. STORY, CoMmentarmes on the Constitution $\$ 1787$ n.2 (4th ed. T. Cooley 1873) (Ist ed. Boston 1833). 
Story wrote in his Commentaries on the Constitution that the meaning of the double jeopardy clause is

that a party shall not be tried a second time for the same offence, after he has once been convicted, or acquitted of the offence charged . . . . But it does not mean, that he shall not be tried for the offence a second time, if the jury have been discharged without giving any verdict . . . for, in such a case, his life or limb cannot judicially be said to have been put in jeopardy. ${ }^{17}$

And he cited Perez as authority for this interpretation of the double jeopardy clause. ${ }^{18}$

In sum, in 1824 when Perez was decided, the question whether a defendant could be retried following a hung jury was not deemed by the Supreme Court to concern the double jeopardy clause of the Constitution.19 Rather, it involved the quite different issue of the authority of a trial court to discharge a jury prior to verdict. This issue was much litigated in England and in this country both before and after Perez. ${ }^{20}$ At common law it was a rule of practice ${ }^{21}$ that

173 J. Stony, Comamentarues on the Constitution \$1781 (Boston 1833) (footnote omitted).

18 Id. n.1.

10 See also Ex parte Lange, 85 U.S. (18 Wall.) 163 (1873). For state courts that took the same position, see cases cited note 13 supra.

20 See, e.g., Nugent v. State, 4 Stew. \& P. 72 (Ala. 1883); Atkins v. State, 16 Ark. 568 (1855); Stone v. People, 3 IIl. (2 Scam.) 326 (1840); O'Brian v. Commonwealth, $69 \mathrm{Ky}$. (6 Bush) 563 (1870); Commonwealth v. Purchase, 19 Mass. (2 Pick.) 521 (1824); Commonwealth v. Bowden, 9 Mass. 494 (1813); Price v. State, 36 Miss. 531 (1858); State v. Moor, 1 Miss. ( 1 Walker) 134 (1823); People v. Goodwin, 18 Johns. 187 (N.Y. Sup. Ct. 1820); People v. Olcott, 2 Johns. Cas. 301 (N.Y. Sup. Ct. 1801); People v. Denton, 2 Johns. Cas. 275 (N.Y. Sup. Ct. 1801); Hurley v. State, 6 Ohio 400 (1834); Winsor v. The Queen, L.R. 1 Q.B. 289 (1866); The Queen v. Charlesworth, 121 Eng. Rep. 786 (Q.B. 1861). See generally Crist v. Bretz, 437 U.S. at 45-47 (Powell, J., dissenting); see also Commonwealth v. Wood, 12 Mass. 313 (1815).

The author of a 1964 Note on double jeopardy recognized that Perez did not involve application of the double jeopardy clause. See Note, Double Jeopardy: The Reprosecution Problem, 77 Harv. L. Rev. 1272, 1276 (1964) ("no final verdict had been entered").

Silverstein, writing ten years later, was apparently the first commentator to offer evidence to support his assertion that Perez was not a double jeopardy case. See Silverstein, Double Jeopardy and Hung Juries: United States v. Castellanos, 5 Ruт.-CaMr. L.J. 218, 221-22 (1974). But see Silverstein, Rebuttal: An Alternative Viewpoint on the Relationship of Unanimous Verdicts and Reasonable Doubt, 11 VAL. L. REv. 29, 31 (1976).

21 Although in England the no-discharge rule protected interests that American courts recognize as double jeopardy interests, the rule apparently was never the basis of a common law double jeopardy bar to reprosecution. The rule was one of jury practice and not one deemed to accord protection to any substantive right of the defendant. See, e.g., Winsor v. The Queen, L.R. I Q.B. 289, 303, 309 (1866); The Queen v. Charlesworth, 121 Eng. Rep. 786, 800-03 (Q.B. 1861). But see 
a jury once sworn could not be discharged before a verdict was returned. ${ }^{22}$ The etiology of the rule is found in the centuries-old practice of drawing the jury from the vicinage in which the crime was alleged to have been committed. ${ }^{23}$ Jurors were not impartial decisionmakers, but were chosen because of their personal knowledge of the facts. ${ }^{24}$ Each jury was uniquely well-suited to decide

Conway and Lynch v. The Queen, 7 Ir. L. Rep. 149, 164-65 (1845). See generally Crist v. Bretz, 437 U.S. at $42-43$ (Powell, J., dissenting); United States v. Bigelow, 14 D.C. (3 Mackey) $393,422-24$ (1884). For the suggestion that the only remedy for violation of the no-discharge rule is a pardon, see The King v. Wade, 168 Eng. Rep. 1196 (1825).

22 The rule has been said to be applicable only to capital offenses, see, e.g., 1 E. CoKe, InstTtutes 227b (17th ed. London 1817) (1st ed. London 1628); M. hate, Pleas of the Crown 267 (London 1678); 2 W. Hawkins, Pleas of the Crown 439 (London 1716), but it has not been so limited in either England or this country. See, e.g., United States v. Bigelow, 14 D.C. (3 Mackey) 393, 422 (1884); The Queen v. Charlesworth, 121 Eng. Rep. 786 (Q.B. 1861). Coke, in his Institutes, stated the rule, but nowhere mentioned either the reason for the rule or the consequence of a failure to adhere to it: "A jury sworne and charged in case of life or member, cannot be discharged by the court or any other, but they ought to give a verdict." 1 E. CoKe, INSTrTUTEs $227 \mathrm{~b}$ (17th ed. London 1817) (1st ed. London 1628).

To speak it here once for all, if any person be indicted of treason, or of felony, or larceny, and plead not guilty, and thereupon a Jury is retorned, and sworn, their verdict must be heard, and they cannot be discharged, ... but ought to give their verdict openly in Court.

3 E. Coke, Instrtortes 110 (London 1644). Hale states that in capital cases a verdict "must be given, and [the] jury cannot be discharged till it be given." M. Hale, Pleas of the Grown 229 (London 1678). See also 1 J. ChitTy, A Practical Treattse on the Crmmat Law 517-18 (Phila. 1819); 2 W. HawkTns, Pleas of the Crown 439 (London 1721).

Blackstone modified Coke's rule somewhat by recognizing an exception for cases of "evident necessity," but he too failed to discuss the rationale of the rule or the effect of its violation. $4 \mathrm{~W}$. BLAckstone, Commentames 360 (R. Burn ed. 1791) (1st ed. Oxford 1766). The Burn edition contains the last revisions made by Blackstone before his death and is the first time any mention of the evident necessity exception appears in the Commentaries.

23 Kirk, "Jeopardy" During the Period of the Year Books, 82 U. PA. L. REv. 602, 609-12 (1934). See People v. Richardson, 138 Cal. App. 404, 407-08, 32 P.2d 433, 435 (1934); 4 W. Brackstone, Commentaries 350 (Oxford 1766); $M$. Haxe, Pleas of the Crown 134-35, 170 (London 1678); 2 W. Hawkins, Pleas OF the CRown 403 (London 1721). See generally 1 J. ChrtTy, A Practical Treatise on the Criminal Law 407 (Phila. 1819).

For a discussion of the history of the rule, see Crist v. Bretz, 437 U.S. at $41-44$ (Powell, J., dissenting).

24 Before English judges rode circuit, "jurors of the counties where the facts occurred were summond to give testimony at Westminster on a trial based on those facts." Kirk, supra note 23, at 612 . Indeed, jurors at one time had an obligation to make inquiries regarding the case they had been summoned to decide. $2 \mathrm{~F}$. Pollock \& F. MAITLAND, THe History of ENGLISH LAW 624-25 (2d ed. 1898).

Thayer points out that not only were jurors chosen from the visne in which the crime was alleged to have occurred, but were often chosen because of some other special qualification, such as their trade. He notes a jury composed of "cooks and fishmongers, where .. [the defendant] was accused of selling bad food." Thayer, The Jury and Its Development II, 5 Harv. L. REv. 295, 300 (1892) (footnotes omitted). 
the case before it and, accordingly, was charged with the responsibility of returning a verdict no matter how arduous that task became. ${ }^{25}$

In the seventeenth century, however, the rule prohibiting discharge of the jury once sworn was put to a new use. During the reign of the Stuarts, judges routinely discharged juries that appeared disposed to acquit ${ }^{26}$ in order to allow the crown an opportunity to strengthen its case and try the defendant again. ${ }^{27}$ The

Blackstone explained the eventual demise of this "policy of ancient law": "But this convenience [of being better able to judge the character of the parties and witnesses] was overballanced by another very natural and almost unavoidable inconvenience: that jurors, coming out of the immediate neighbourhood, would be apt to intermix their prejudices and partialities in the trial of right." $3 \mathrm{~W}$. Blackstone, Commentanies 359-60 (Oxford 1766). See 4 id. 350 (commentary on civil juries applicable to criminal panels as well). See generally 1 J. Cerrsx, A Practical Treatise on the Crminal Law 501-02 (Phila. 1819).

25 The English courts used a variety of methods to insure that the jury reached a unanimous verdict. Jurors were deprived of food and drink during deliberations. 1 W. Holdsworth, A History of English LAw 318-19 (7th ed. rev. 1956). And if, by the expiration of the court's term, the jurymen had not yet agreed on a verdict, the rule against discharge required that they follow the judge to the next village, in order to continue their deliberations. "In cases of life and member, if the jury cannot agree before the Judges depart, they are to be carried in carts after them; so they may give their verdict out of the county." The King v. Ledgingham, 86 Eng. Rep. 67 (K.B. 1682). See Commonwealth v. Purchase, I9 Mass. (2 Pick.) 521, 525 (1824).

In addition, at least one court imprisoned a juror unable to agree with the majority. Thayer, The Jury and Its Development II, 5 HaRv. L. REv. 295, 297 (1892).

These practices were disapproved of, however, by American courts concerned about the potential for coerced verdicts. See Commonwealth v. Purchase, 19 Mass. (2 Pick.) 521, 525-26 (1824); People v. Olcott, 2 Johns. Cas. 301, 309 (N.Y. Sup. Ct. 1801); Commonwealth v. Clue, 3 Rawle 498, 502-03 (Pa. 1831). The court in Clue reversed the conviction of defendant obtained at a second trial because of the improper refusal of the first trial judge to allow the jurors food or drink during their deliberations. The court's failure to provide refreshment exacerbated the jury's inability to agree and did not constitute sufficient necessity to warrant discharge of the jury. Id. 501-03. See also $1 \mathrm{~J}$. ChrTTY, A Practical Treatise on the Cramnal Law 529, 631-34 (Phila. 1819).

26 See State v. Garrigues, 2 N.C. (1 Hayw.) 241, 241 (1795). See also The Queen v. Charlesworth, 121 Eng. Rep. 786, 801 (Q.B. 1861).

27 The abuse of this long-standing practice prompted a judicial reaction. See The Queen v. Charlesworth, I21 Eng. Rep. at 801-02.

For an example of this practice, see Trial of Ireland (Ireland's Case), 7 How. St. Tr. 79 (1678), in which the case of two Jesuit priests, Whitebread and Fenwick, brought to trial with three others for high treason, was removed from the jury's consideration "until more proof may come in." Id. 120. The prisoners were returned to prison and, more evidence apparently having been assembled, were retried six months later. Trial of Whitebread (Whitebread's Case), 7 How. St. Tr. 311 (1679). Their claim of former jeopardy fell upon impatient ears, id. 315-17; trial proceeded and both were convicted. Id. 417-18. They were sentenced to death and hanged one week later. Trial of Langhorn (Langhorn's Case), 7 How. St. Tr. 41, 489-90, 501 (1679).

See generally Crist v. Bretz, 437 U.S. at $42-43$ (Powell, J., dissenting); Winsor v. The Queen, L.R. I Q.B. 289, 304 (1866); The Queen v. Charlesworth, 
no-discharge rule was invoked ${ }^{28}$ to protect against such abuse and has remained a part of English jurisprudence as a check against government harassment and oppression.

A majority ${ }^{29}$ of the courts in this country, including the Supreme Court in Perez, took the position that the trial court had authority to discharge the jury before verdict in cases of evident or manifest necessity. ${ }^{30}$ Conversely, absent such necessity, discharge was improper, and the rule developed that in those cases the defendant could not be retried. ${ }^{31}$

121 Eng. Rep. 786, 801 (Q.B. 1861); M. Fruedland, Double JeOpardy 13-14, 2I-25 (1969); J. Sigler, Double JEopardy 128 (1969).

Hale not only recognized the practice of discharging the jury for the purpose of allowing the prosecutor to bolster his case, he favored it, lest justice be frustrated in cases in which evidence of guilt could have been, but simply was not, mustered. 2 M. Harie, The Hrstory of the Pleas of the Crown 294-95 (London 1736).

28 The rule was announced in the form of a resolution following a meeting of the judges of England and not as a decision in a particular case. See generally United States v. Bigelow, 14 D.C. (3 Mackey) 393, 415-16 (1884).

29 See State v. Garrigues, 2 N.C. (I Hayw.) 24I, 241 (1795): "[T] he rule as laid down by my Lord Coke was revived with this addition, that a jury should not be discharged in a capital case unless for the benefit of the prisoner . . . " The court in Garrigues barred retrial of defendant following a hung jury. See note 160 infra. See also In re Spier, 12 N.C. (1 Dev.) 491 (1828).

${ }^{30}$ See, e.g., United States v. Coolidge, 25 F. Cas. 622, 623 (C.C.D. Mass. 1815 ) (No. 14,858); United States v. Workman, 28 F. Cas. 771, 773 (D.C.D. La. 1807) (No. 16,764); Nugent v. State, 4 Stew. \& P. 72, 77 (Ala. 1833); Atkins v. State, 16 Ark. 568, 579 (1855); Stone v. People, 3 Ill. (2 Scam.) 326, 337, 338 (1840); O'Brian v. Commonwealth, $69 \mathrm{Ky}$. (6 Bush) 563, 568 (1870); Hoffman v. State, 20 Md. 425, 435 (I863); Commonwealth v. Bowden, 9 Mass. 494, 495 (1813); Price v. State, 36 Miss. 531, 543-44 (1858); People v. Denton, 2 Johns. Cas. 275, 277 (N.Y. Sup. Ct. 1801); Hurley v. State, 6 Ohio 400, 402-03 (1834); Commonwealth v. Cook, 6 Serg. \& Rawl. 577, 585-86 (Pa. 1822); State v. M'Kee, 17 S.C.L. (I Bail.) 65I, 653 (1830). See also Commonwealth v. Purchase, 19 Mass. (2 Pick.) 521, 524-25 (1824); People v. Goodwin, 18 Johns. 187, 205 (N.Y. Sup. Ct. 1820); People v. Olcott, 2 Johns. Cas. 301, 307 (N.Y. Sup. Ct. 1801); In re Spier, 12 N.C. (1 Dev.) 491, 499 (1828); Stewart v. State, 15 Ohio St. 155, 161 (1864); Poage v. State, 3 Ohio St. 229, 239-40 (1854).

31 Retrial following an improper discharge of the jury may not have been barred in this country absent the "blending" of the common law no-discharge rule with the double jeopardy clause of the Constitution by state and federal courts. See Crist v. Bretz, 437 U.S. at 45 (Powell, J., dissenting).

For example, two early cases in which retrial was barred were Commonwealth v. Cook, 6 Serg. \& Rawl, 577 ( $\mathrm{Pa}$. 1822), and Commonwealth v. Clue, 3 Rawle 498 (Pa. 1831), both decided in Pennsylvania, a jurisdiction holding that jeopardy attaches before verdict. Thus, although the court spoke in terms of "manifest necessity," it did so in the context of double jeopardy.

In United States v. Shoemaker, 27 F. Cas. 1067 (C.C.D. III. 1840) (No. 16,279), Justice McLean, sitting on circuit, concluded that once the trial had begun, the prosecutor was not entitled to enter a nolle prosequi because his evidence was not sufficient to convict. He analogized to the mistrial case, stating that "it would be absurd to suppose that after evidence given, the prosecutor might be allowed to withdraw a juror merely because the proof would not amount to conviction." Id. 1068. Having decided that the case was not within the double jeopardy clause 
Thus, Perez did not involve application of the double jeopardy clause; it was simply one step in the developing common law regarding the propriety of discharging a jury before verdict. ${ }^{32}$ Indeed, given its premise that jeopardy did not attach before verdict, the Supreme Court could not have approached the case otherwise. Under the Court's view, the common law rule regarding discharge of the jury and the double jeopardy bar could never be implicated in the same case: the no-discharge problem arose only when the jury was discharged before rendering a verdict; the double jeopardy problem arose only after a verdict was returned. ${ }^{33}$

Since Perez, however, the Supreme Court has held that jeopardy attaches before a verdict is rendered ${ }^{34}$-specifically, when the jury

because defendant was not charged with a capital offense, id., Justice McLean turned to the question whether other grounds barred retrial. $\mathrm{He}$ based his conclusion-that retrial was barred-on "principle" because he could find no supporting authority. Id. 1069.

See also State v. Garrigues, 2 N.C. (1 Hayw.) 241, 241-42 (1795).

32 See United States v. Bigelow, 14 D.C. (3 Mackey) 393, 424-26 (1884):

In short, the alleged rule as to the discharge of a jury, with its alleged consequences, is not in any sense a part of our constitutional rule. At common law the rule that a person should not be tried twice for the same offence, and the rule concerning the discharge of a jury, whatever it may have been, were separate and distinct, and even a disregard of the one was not a violation of the other. The first was put into our Constitution; the other was not.

Contrast the view of Justice Powell that the no-discharge rule was unwittingly absorbed into the double jeopardy clause: "Thus, the state courts were putting Lord Coke's rule to a use similar to that of the 17th-century English judges, but they did so-with no apparent awareness of the novelty of their action-under the rubric of the Double Jeopardy Clause." Crist v. Bretz, 437 U.S. at 46 (Powell, J., dissenting).

33 Compare Justice Washington's words in United States v. Haskell, 26 F. Cas. 207, 212 (C.C.E.D. Pa. 1823) (No. 15,231):

We are in short of opinion, that the moment it is admitted that in cases of necessity the court is authorised to discharge the jury, the whole argument for applying this article of the constitution to a discharge of the jury before conviction and judgment is abandoned, because the exception of necessity is not to be found in any part of the constitution; and I should consider this court as stepping beyond its duty in interpolating it into that instrument, if the article of the constitution is applicable to a case of this kind. We admit the exception, but we do it because that article does not apply to a jeopardy short of conviction.

See also United States v. Bigelow, 14 D.C. (3 Mackey) 393, 426 (1884): "[W]e hold that no rule touching the discharge of the jury has, by implication, been incorporated in or referred to by the [fifth amendment] ...."

34 Although it was clear before Downum v. United States, 372 U.S. 734 (1963), that in a federal case jeopardy attached before verdict, the exact point at which it attached had not been fixed. See, e.g., Kepner v. United States, 195 U.S. 100, 128 (1904):

[A] person has been in jeopardy when he is regularly charged with a crime before a tribunal properly organized and competent to try him .... 
is impaneled and sworn. ${ }^{35}$ In so doing, it created an issue that did not obtain when Perez was decided: the effect of the double jeopardy clause on the retrial of cases that abort before verdict. The Court, however, has repeatedly read Perez as if it had established the standard for resolving the extent of the defendant's double jeopardy protection following a mistrial. ${ }^{36}$ Although recently acknowledging the likely inaccuracy of that view, ${ }^{37}$ the Court treated the matter as one "of academic interest only." 38 In so doing, it simply compounded error.

Undoubtedly in those jurisdictions where a trial of one accused of crime can only be to a jury, and a verdict of acquittal or conviction must be by a jury, no legal jeopardy can attach until a jury has been called and charged with the deliverance of the accused.

See also Gori v. United States, 367 U.S. 364 (1961).

In Downum, however, the Court held that double jeopardy barred retrial of a defendant whose first trial was terminated after the jury had been sworn, but before any evidence had been introduced. Downum has been read as authority for the rule that in a federal case jeopardy attaches when the jury is impaneled and sworn. See United States v. Martin Linen Supply Co., 430 U.S. 564, 569 (1977); Serfass v. United States, 420 U.S. 377,388 (1975).

35 In 1978, the Supreme Court held that the federal rule-that jeopardy attaches when the jury is impaneled and sworn-is applicable to the states. Crist v. Bretz, 437 U.S. 28 (1978).

In a bench trial, jeopardy attaches when evidence is introduced. Serfass v. United States, 420 U.S. 377 (1975).

${ }^{36}$ See, e.g., cases cited in notes 2 \& 11 supra.

The Supreme Court was not alone in its misreading of Perez. Other courts and numerous commentators have cited Perez as a fifth amendment case despite the glaring absence of any reference to the Constitution in Justice Story's opinion. See, e.g., United States v. Klein, 582 F.2d 186 (2d Cir. 1978), cert. denied, 439 U.S. 1072 (1979); Nelson v. District Court, 543 F.2d 631 (8th Cir. 1976); United States ex rel. Stewart v. Hewitt, 517 F.2d 993 (3d Cir. 1975); United States v. Means, 513 F.2d 1329 (8th Cir. 1975); McNeal v. Hollowell, 481 F.2d 1145 (5th Cir. 1973), cert. denied, 415 U.S. 951 (1974); Sanford v. Robbins, 115 F.2d 435 (5th Cir. 1940), cert. denied, 312 U.S. 697 (194I); Pratt v. United States, 102 F.2d 275 (D.C. Cir. 1939); Blair v. White, 24 F.2d 323 (8th Cir. 1928); People ex rel. Mosley v. Carey, 74 Ill. 2d 527, 387 N.E.2d 325, cert. denied, 444 U.S. 940 (1978); State v. Lynch, 79 N.J. 327, 399 A.2d 629 (1979).

See, e.g., Wurzburg \& Gross, Double Jeopardy: Dismissal and Government Appeal, 13 Gonz. L. Rev. 337, 340 (1978); Note, Double Jeopardy: Discretion of a Trial Judge to Declare a Mistrial on the Basis of a Hung Jury, 44 FondHAM L. Rev. 389 (1975); Comment, The Double Jeopardy Dilemma: Reprosecution After Mistrial on Defendant's Motion, 63 IowA L. Rev. 975, 977 (1978); Comment, Double Jeopardy and Reprosecution After Mistrial: Is the Manifest Necessity Test Manifestly Necessary?, 69 Nw. U.L. REv. 887, 892 (1975). But see Silverstein, Double Jeopardy and Hung Juries: United States v. Castellanos, 5 Rur.-CaM. L.J. 218, 221-22 (1974); Note, Double Jeopardy: The Reprosecution Problem, 77 HARv. L. REv. 1272,1276 (1964).

37 Crist v. Bretz, 437 U.S. at 34 n.10; see note 4 supra.

38 Crist, 437 U.S. at 34 n.10; see note 5 supra. 


\section{Manifest Necessity and Double Jeopardy Policies}

The Supreme Court held in United States $v$. Perez ${ }^{39}$ that the defendant may be retried if manifest necessity required discharge of the first jury. Due to the misreading of the case, the Perez common law rule became constitutional doctrine. Of what significance is this error? In some cases it is inconsequential; in others, fatal.

Two categories of cases may be posited. Take first those in which, after the facts are found, the need to terminate the trial is open to debate. ${ }^{40}$ In these cases, use of the manifest necessity test may do little harm. The court can decide the underlying retrial question on the basis of double jeopardy policies and then resolve the debatable manifest necessity question accordingly.

The other category of cases, however, involves those in which, after the facts have been found, the need to discharge the jury is beyond debate. It is here that the misconstruction of Perez does its mischief. The court, forced to its conclusion regarding retrial by the finding of a presence or absence of manifest necessity to terminate the proceedings, is unable to take double jeopardy policies into account. 41

The hung jury is the paradigm of the second situation. The need to terminate the trial is beyond argument. If the jury is genuinely deadlocked, it should be discharged; ${ }^{12}$ forcing it to con-

3922 U.S. ( 9 Wheat.) 579 (1824).

40 See, e.g., Illinois v. Somerville, 410 U.S. 458 (1973), a case in which the prosecutor proceeded to trial with a fatally defective indictment. Because any conviction obtained would be reversed on appeal, it might be argued plausibly that the necessity to terminate the trial and begin again is manifest. On the other hand, it might be argued that termination is not necessary because the trial will not inevitably be for naught: defendant might be acquitted. See also Harris v. Young, 607 F.2d 1081 (4th Cir. 1979), cert. denied, 444 U.S. 1025 (1980); People v. Benton, 402 Mich. 47, 260 N.W.2d 77 (1977). See generally Mayers \& Yarbrough, Bis Vexari: New Trials \& Successive Prosecution, 74 Harv. L. Rev. 1, 3-8 (1960); Comment, Double Jeopardy and Reprosecution After Mistrial: Is the Manifest Necessity Test Manifestly Necessary?, 69 Nw. U.L. Rev. 887, 890 (1975).

41 Even in instances such as this, however-in which the presence or absence of manifest necessity to terminate is beyond debate once the facts are foundutilization of manifest necessity as the litmus test is of small practical import as long as the result accords with that which a double jeopardy policy analysis would produce. At times this may occur. A case involving the death of the trial judge, for example, is one in which the manifest necessity doctrine, permitting retrial, does square with constitutional policies.

42 While the point has been debated, beyond cavil the more civilized view is that which recognizes the need to discharge a genuinely deadlocked jury. See, e.g., State v. M'Kee, 17 S.C.L. (I Bail.) 651, 653 (1830):

The proposition, that the Judge can have them conveyed from Court to Court, on his circuit, until they do agree, is at war with all our notions, either of their rights, or of the rules of justice and propriety. It has 
tinue deliberations would be pointless. ${ }^{43}$ The manifest necessity test has been met and language cannot be strained to conclude otherwise. Yet the undeniable fact of manifest necessity to release a hopelessly deadlocked jury does not logically compel the conclusion that the state must then enjoy a second opportunity to convict the defendant. To the contrary, double jeopardy policies point to the opposite conclusion. Before this can be established, however, an examination of the policies of the double jeopardy clause is necessary. ${ }^{44}$

\section{A. The Traditional Balancing}

The Supreme Court, in discussing double jeopardy policies, has frequently spoken of the need to weigh the competing interests of the defendant and state. ${ }^{45}$ But what precisely are these interests? Take first those of the defendant.

never been acted on in this State; and $I$ have no hesitation in saying, that it is not law. It is equally absurd to say, that the jury must be starved into a verdict. Their verdict ought to be the result of calm, and deliberate reflection, and not of force.

Accord, Winsor v. The Queen, L.R. I Q.B. 390, 394 (1866). Contra, Ned v. State, 7 Port. 187, 214 (Ala. 1838); State v. Garrigues, 2 N.C. (1 Hayw.) 241, 242 (1795); In re Spier, 12 N.C. (1 Dev.) 491, 503 (1828).

During the whole of their absence, [jurymen] are not to eat or drink without the permission of the justices, ... And they are not only prohibited from taking refreshment, but are fineable if they have taken any thing eatable with them, when they retire, though they have not actually eaten ....

.... And if they do not agree before the judges at the assizes depart, they may be carried with them from place to place until they become unanimous.

1 J. Chitty, A Practical Treatuse on refe Crmmanal Law 632-34 (2d ed. T. Huntington 1832) (1st ed. Phila. 1819) (footnotes omitted). 43 Or perhaps dangerous, in view of the possibility of a coerced verdict. See The Queen v. Charlesworth, I21 Eng. Rep. 786, 802 (Q.B. 1861):

We do take upon ourselves, without the consent of the parties, . . . to discharge the jury when we are satisfied that they have fully considered the case and cannot agree; and I hope no Judge will shrink from taking that course; for, if a jury cannot agree, we ought not to coerce them by personal suffering, nor ought we to expose parties to the danger of a verdict which is not the result of conviction in the minds of the jury, but produced by suffering of mind or body.

See also note 42 supra.

44 The double jeopardy clause protects against multiple punishment for the same offense as well as against multiple trials. This Article focuses on policies related to the multiple trial problem. For a discussion of the multiple punishment aspect of double jeopardy, see Westen \& Drubel, Toward a General Theory of Double Jeopardy, 1978 Sup. CT. Rev. 81, 108-22.

45 See, e.g., United States v. Scott, 437 U.S. 82, 91-94 (1978); Arizona v. Washington, 434 U.S. 497, 503-05 (1978); Mlinois v. Somerville, 410 U.S. 458,471 
In United States $v$. Green, ${ }^{46}$ the Court described the purpose of the double jeopardy bar:

The underlying idea ... is that the State with all its resources and power should not be allowed to make repeated attempts to convict an individual for an alleged offense, thereby subjecting him to embarrassment, expense, and ordeal and compelling him to live in a continuing state of anxiety and insecurity, as well as enhancing the possibility that even though innocent he may be found guilty. ${ }^{47}$

The interests described in Green as the heart of the defendant's double jeopardy protection are thus two: avoiding the strain of repeated prosecution (his repose interest); and limiting the risk of erroneous conviction.

The emotional, physical, psychological, and economic ${ }^{48}$ harm visited by a repetition of trials is obvious. ${ }^{49}$ As the defendant's resources thin, the possibility of presenting an adequate defense decreases. Further, in a second trial, the defendant must face a prosecutor whose experience from the first trial may be put to good use. For example, witnesses may be encouraged to do further soul-searching or even coached until recollection accords with prosecutorial goals. ${ }^{50}$ These, plus the not insignificant factor of a

(1973); Downum v. United States, 372 U.S. 734, 736 (1963); Green v. United States, 355 U.S. 184, 187-88 (1957); Wade v. Hunter, 336 U.S. 684, 689 (1949).

The Court has cautioned, however, that double jeopardy involves neither "a balancing of the equities," Burks v. United States, 437 U.S. I, 11 n.6 (1978), nor a "due process sliding "interest balancing test," "Crist v. Bretz, 437 U.S. 28, 37 n.16 (1978).

46355 U.S. 184 (1957).

47 Id. 187-88.

48 Even if defendant is indigent, a criminal prosecution may have substantial economic consequences, especially in states that allow recoupment of assigned counsel fees.

49 Additionally, for defendants who are denied or unable to post bond, retrial means continued incarceration.

50 And even without coaching, the testimony of witnesses can change subtly but significantly from one trial to the next. No one wants to look like a fool or a liar. A witness whose testimony was weak will perhaps strengthen it by filling in gaps or becoming certain of that of which he had previously been less sure. Following is a description of such an occurrence:

[T] he government witnesses came to drop from their testimony impressions favorable to defendant. Thus a key prosecution witness, the last person to see appellant and the deceased together, who began by testifying that they had acted that evening like newlyweds on a honeymoon, without an unfriendly word spoken, ended up by saying for the first time in four trials that the words between them had been "firm," and possibly harsh and "cross."

We also note that the police officer who readily acquiesced in the two "hung jury" trials that appellant was "hysterical," later withheld that 
different fact-finder, perhaps this time more amenable to the prosecutor's point of view, ${ }^{51}$ can increase the risk that although innocent the defendant may be convicted. ${ }^{52}$

Before turning to the interest of the state, one argument regarding the scope of the defendant's interest must be addressed. In referring to the interest of the accused protected under the double jeopardy clause, the Court has spoken of the "valued right to have his trial completed by a particular tribunal." 53 Because this valued right has also been described as the "valued right to go to the first jury" 54 and "perhaps, end the dispute then and there with an acquittal," 55 it might be argued that this right extends only to the opportunity for a verdict rather than to having the case culminate in a verdict or be terminated for all time.56

If the opportunity for a verdict were the extent of the defendant's double jeopardy protection, then the Court's present resolution of the hung jury issue is not erroneous. Under this view, the hung jury question is easily resolved, even as a matter of policy: the defendant can be retried because he has not been deprived of his valued right. The case went to the first jury; the defendant had the opportunity to end the dispute then and there with an acquittal; the jury refused to do so. Defendant's interests having been fully vindicated, no balancing need be done.

In support of this narrower "opportunity" view, it has been suggested that the defendant's interest is grounded in the possibility

characterization. This shift, though less dramatic, was by no means inconsequential in view of the significance of appellant's condition at the time he made a statement inconsistent with what he later told another officer.

Carsey v. United States, 392 F.2d 810, 813-14 (D.C. Cir. 1967) (Leventhal, J., concurring) (footnotes omitted).

For an excellent discussion of such problems, see J. Frank \& B. Frank, Not GoIrTY 209-11 (1957).

s1 "Without a rule of finality no procession of juries could effectively acquit a defendant, but a single jury could convict. The prosecutor could keep trying until he found an accommodating panel." Comment, Twice in Jeopardy, 75 YALE L.J. 262,278 (1965).

52 Alternatively, the defendant may see little choice but to capitulate by entering a guilty plea.

53 Wade v. Hunter, 336 U.S. 684, 689 (1949); accord, Arizona v. Washington, 434 U.S. 497,503 (1978); United States v. Jorn, 400 U.S. 470 , 484 (1971) (plurality opinion).

54 United States v. Scott, 437 U.S. 82, 100 (1978).

55 United States v. Jorn, 400 U.S. 470,484 (1971) (plurality opinion).

56 See also Crist v. Bretz, 437 U.S. 28, 38 (1978) ("the valued right to continue with the chosen jury); Mlinois v. Somerville, 410 U.S. 458, 471 (1973) ("the interest of the defendant in having his fate determined by the jury first impanelled"). Justice Powell, dissenting in Crist, 437 U.S. at 53, refers to it as "the hitherto unexplained "valued right' to a particular jury." 
that the first twelve jurors are favorably disposed to him.57 This notion finds support in neither logic nor the law. No reason exists to believe that the first twelve jurors will be any more inclined to acquit than any other twelve drawn by a similar process. ${ }^{58}$ Not every defendant will prefer to have the first twelve decide his fate simply because they were first. What the defendant would preferand it is here that the valued right takes on significance-is the avoidance of a multiplicity of trials, which would not only prolong the misery of his confrontation with society, but increase the risk of erroneous conviction as well.

These points have not escaped notice by the Supreme Court. As Justice Stevens stated in Arizona v. Washington: ${ }^{59}$

The reasons why this "valued right" merits constitutional protection are worthy of repetition. Even if the first trial is not completed, a second prosecution may be grossly unfair. It increases the financial and emotional burden on the accused, prolongs the period in which he is stigmatized by an unresolved accusation of wrongdoing, and may even enhance the risk that an innocent defendant may be convicted. ${ }^{00}$

Justice Stevens is, of course, drawing on the oft-quoted passage in United States $v$. Green. ${ }^{61}$ "Valued right" appears to be a short-

57 "The reason for holding that jeopardy attaches when the jury is empaneled and sworn lies in the need to protect the interest of an accused in retaining a chosen jury." Crist v. Bretz, 437 U.S. at 35. The Court has also spoken of "the importance to the defendant of being able, once and for all, to conclude his confrontation with society through the verdict of a tribunal he might believe to be favorably disposed to his fate." United States v. Jorn, 400 U.S. 470, 486 (1971) (plurality opinion). See also Illinois v. Somerville, 410 U.S. 458, 472-73 (1973) (White, J., dissenting). But a leading commentator has noted that the logical extension of this view is that jeopardy should attach at the beginning of the jury selection process. See Schulhofer, Jeopardy and Mistrials, 125 U. PA. L. REv. 449, 501-04, 512-14 (1977). See also Crist v. Bretz, 437 U.S. at 51 (Powell, J., dissenting):

Moreover, the Double Jeopardy Clause cannot be viewed as a guarantee of the defendant's claim to a factfinder perceived as favorably inclined toward his cause. That interest does not bar pretrial reassignment of his case from one judge to another, even though he may have waived jury trial on the belief that the original judge viewed his case favorably. Thus, the Double Jeopardy Clause interest in having his "trial completed by a particular tribunal," Wade v. Hunter, 336 U.S., at 689 , must refer to some interest other than retaining a factfinder thought to be disposed favorably toward defendant.

58 Of course, in a particular case they may in fact be more inclined to the defendant's point of view, but the defendant could rarely be sure of this. See Schulhofer, supra note 57, at 504.

59434 U.S. 497 (1978).

60 Id. 503-04 (footnotes omitted).

61 See text accompanying note 47 supra. 
hand expression representing those interests of the defendant recognized by the Court in Green as protected by the double jeopardy clause. ${ }^{62}$ A narrow view of the term limiting it to an opportunity for a verdict of acquittal would, in the hung jury context at least, simply be inconsistent with the teachings of Green and Washington.

If the defendant's interests are those recognized by the Court, his valued right must represent his interest in having his case either culminate in a verdict or terminate for all time. ${ }^{63}$ Were it otherwise, the accused would be subjected to the psychic and financial trauma of a second trial in which he would face a prosecutor determined to present a stronger case than the one that led to an inconclusive result. The risk is obvious that sooner or later the vigorous application of the state's resources could lead to the conviction of even the blameless. ${ }^{.4}$

Yet to state that retrial after a hung jury is inconsistent with vindication of the defendant's valued right does not necessarily dispose of the question whether such retrial is constitutionally permissible. The term "valued right" can be misleading. The Court does not use it to describe an absolute right, but to represent interests that, although important, can be overridden by weightier ones of the state. In Washington, for example, the Court acknowledged the defendant's constitutionally protected interest in avoiding multiple trials-an interest it termed his "valued right." ${ }^{65}$ It stated nonetheless that the defendant's interest was sometimes subordinate to that of the public, which it described as "affording the prosecutor one full and fair opportunity to present his evidence to an impartial jury." 66

Of particular concern for present purposes is Justice Stevens's dictum in Washington: "[T] he trial judge may discharge a genu-

62 The term "valued right" appears to have sprung full blown from the pen of Justice Black in Wade v. Hunter, 336 U.S. 684, 689 (1949).

${ }^{63}$ Arguably, the defendant's Green interests and his valued right are separate interests, each protected under the double jeopardy clause. The language in Washington, however, suggests otherwise. Additionally, it makes no difference whether the valued right (narrowly viewed) is separate from the Green interests because the Court has never limited the defendant's double jeopardy protection to his valued right. Indeed, Green itself supports the opposite conclusion. The jury was given, but did not return a verdict on, the first degree murder charge. Green enjoyed his opportunity to go to the first jury. Yet the Court concluded that retrial was barred.

64 See note 51 supra.

65434 U.S. at 503.

${ }^{66} \mathrm{Id}$. 505. Because Washington involved a mistrial entered without defendant's consent-the situation in which the Perez doctrine continues to intruderesolution of the competing interests of defendant and the state was determined by the manifest necessity test. See text accompanying note 71 infra. 
inely deadlocked jury and require the defendant to submit to a second trial. This rule accords recognition to society's interest in giving the prosecution one complete opportunity to convict those who have violated its laws." "7 This language is opaque. In a case culminating in a hung jury, the prosecutor's opportunity to convict was complete. All that was lacking was the desired result. Given the Court's formula, retrial should be barred: there is no need to balance the competing interests of the defendant and the state because the state's interest has been fully vindicated. Yet the Court's conclusion is exactly the reverse: retrial is permissible. ${ }^{68}$ Because the Court is according the prosecutor a second chance to present his case to a jury, it must be of the view that "opportunity to convict" extends not only to the opportunity for a verdict, but to a verdict itself. Put another way, just as a defendant who has gone through one incomplete trial has a recognized interest in "being able, once and for all, to conclude his confrontation with society," 60 so, too, does the state have a legitimate claim to retry him to obtain a resolution on the merits. ${ }^{70}$ After a trial culminating in a deadlocked jury, neither the defendant's nor the state's interests have been fully vindicated. In the hung jury case, as in other mistrials, the Court's resolution of this conflict turns on the presence or absence of a manifest necessity for the mistrial. The Court inevitably concludes that retrial following a hung jury may occur as a matter of course because the necessity to discharge a genuinely deadlocked jury is as manifest as can be. ${ }^{71}$

If, as this Article suggests, this result is in error, the fault is not with the formulation of the state's interest, but with the use of the manifest necessity doctrine to determine when the state's interest overrides that of defendant. ${ }^{22}$ Justice Stevens's formulation actually understates society's interest. There is nothing inherently illegitimate in the state's seeking repeated opportunities to prosecute those it believes guilty. Any restraint on retrial by the state must be imposed not because the state's interest is anything less

67434 U.S. at 509.

68 Id. 509-10.

69 United States v. Jorn, 400 U.S. 470, 486 (1971) (plurality opinion).

70 The Court has long recognized "the public's interest in fair trials designed to end in just judgments," Wade v. Hunter, 336 U.S. 684, 689 (1949).

71 See cases cited at notes 2 \& 11 supra.

72 Use of the Perez manifest necessity test as constitutional doctrine has been criticized elsewhere. See, e.g., Schulhofer, Jeopardy and Mistrials, 125 U. PA. I. Rev. 449 (1977); Comment, Double Jeopardy and Reprosecution After Mistrial: Is the Manifest Necessity Test Manifestly Necessary?, 69 Nw. U.L. REv. 887 (1975). 
than convicting the guilty-no matter how many trials that may take-but because the Constitution limits government action in order to safeguard individual interests. ${ }^{73}$

\section{B. Double Jeopardy Limits on Government Action}

The state's prosecutorial interest is considerable and, unsurprisingly, at loggerheads with the defendant's valued right. The solution to the hung jury problem lies in determining how the standoff should be resolved. Pointing to the inevitable presence of a manifest necessity to discharge a deadlocked jury simply forecloses analysis. Rather, the matter must be determined under double jeopardy policies-that is, policies that will indicate the weight to be assigned the conflicting interests of the defendant and the state. These policies can be found by analyzing cases falling into four categories: unavoidable mistrials; mistrials caused by prosecutorial error; acquittals and reversed convictions; ${ }^{74}$ and dismissals. ${ }^{75}$ The effect of double jeopardy policy on the hung jury question can then be considered and the thesis of this Article demonstrated: resolution of the hung jury issue continues to be plagued by historical accident ${ }^{76}$ and is wholly inconsistent with current double jeopardy doctrine.

73 "[S]ociety's awareness of the heavy personal strain which a criminal trial represents for the individual defendant is manifested in the willingness to limit the Government to a single criminal proceeding to vindicate its very vital interest in enforcement of criminal laws." United States v. Jorn, 400 U.S. 470,479 (1971). For the view that the purpose of the double jeopardy clause is to protect the individual by limiting the prosecutorial power of the state, see J. Siglear, Dourle JEOPARDY passim (1969).

74 These include cases in which, after a full trial, the judge or jury, as trier of fact, returns either a verdict of guilty that is reversed on appeal or a verdict of acquittal, see, e.g., Burks v. United States, 437 U.S. 1 (1978); United States v. Ball, 163 U.S. 662 (1896); those in which the trial court directs the jury to enter a verdict of acquittal, see, e.g., Fong Foo v. United States, 369 U.S. 141 (1961); and those in which the trial court itself enters a verdict of acquittal, whether before the case is submitted to the jury, see, e.g., Sanabria v. United States, 437 U.S. 54 (1978); note 75 infra, afier the jury has returned a verdict of guilty, see, e.g., United States v. Wilson, 420 U.S. 332 (1975), or where the jury is genuinely deadlocked, see, e.g., United States v. Martin Linen Supply Co., 430 U.S. 564 (1977).

75 Arguably, the Court does not treat the dismissal cases as a separate category, but instead includes them within various other recognized groups of cases. For example, in Lee v. United States, 432 U.S. 23 (1977), the Court found the trial court's dismissal of the indictment "functionally indistinguishable from a declaration of mistrial at the defendant's request." Id. 31. Accord, United States v. Scott, 437 U.S. 82 (1978) (dismissal entered on defendant's motion on a basis unrelated to guilt or innocence treated as defendant's motion for mistrial).

${ }^{76}$ See notes 8-38 supra \& accompanying text. 


\section{Unavoidable Mistrials}

As stated above, cases in which the need to discharge the jury is beyond dispute teach little about double jeopardy policy because the manifest necessity test is necessarily dispositive. ${ }^{7 \pi}$ For example, an unexpected and untoward event that is the fault of none of the participants may disrupt the normal trial process. ${ }^{78}$ The judge ${ }^{79}$ or a juror ${ }^{80}$ may become incapacitated or juror bias may be discovered. $^{81}$ Because there is no alternative to termination of the proceedings, the prosecutor is permitted to present his case again. That retrial is permitted here, as after a hung jury, is simply due to the undeniable existence of a manifest necessity to end the first trial. ${ }^{82}$ Conversely, if the trial judge feels impelled to terminate a trial to enjoy a long-anticipated holiday, the lack of manifest necessity is beyond dispute, and retrial is proscribed. ${ }^{83}$

77 See text accompanying notes $41-44$ supra.

78 While technically the hung jury case is a mistrial, it differs in a significant way from other cases included in this category. Each of the other cases involves an unexpected, unforeseen event that interrupts the normal trial process, an event that has been characterized as a breakdown in the judicial machinery: for example, the judge dies or is taken ill, juror bias is discovered, or it becomes impossible to hold the trial at the place or time originally scheduled. See Wade v. Hunter, 336 U.S. 684 (1949). The hung jury, however, does not result from this kind of event. Nor is it unexpected, occurring in approximately one of every twenty trials. See note 7 supra. Additionally, the judicial machinery has not broken down, but has run its full course. The jurors engaged in uninterrupted deliberations; they simply failed to agree.

Thus, even if manifest necessity is deemed to represent an acceptable accommodation of the competing interests of defendant and the state in the usual mistrial case, it should be recognized that the hung jury is a mistrial in form only; substantively it does not fit the mistrial mold for double jeopardy purposes.

See generally Stream, Double Jeopardy Clause of the Fifth Amendment, N.Y.L.J., pt. 1, Sept. 30, 1970, at 1, col. 3; pt. 2, Oct. 1, 1970, at 1, col. 3; pt. 3 , Oct. 2,1970 , at 1 , col. 3 (especially pt. 3 ).

${ }^{79}$ See, e.g., Freeman v. United States, 237 F. 815 (2d Cir. 1916).

80 See, e.g., United States v. Potash, 118 F.2d 54 (2d Cir.), cert. denied, 313 U.S. 584 (1941).

81 See, e.g., Arizona v. Washington, 434 U.S. 497 (1978) (prejudicial and improper comment by defense counsel during opening argument); Thompson $v$. United States, 155 U.S. 271 (1894) (juror a member of grand jury that returned indictment against defendant); Simmons v. United States, 142 U.S. 148 (1891) (juror acquainted with defendant).

82 As stated earlier in this Article, there may be leeway in finding the facts. To the extent this is possible, a finding of manifest necessity may be nothing more than a conclusion. See, e.g., Arizona v. Washington, 434 U.S. 497, 511 (1978). But see United States v. Whitlow, 110 F. Supp. 871 (D.D.C. 1953), in which retrial was barred following the trial court's sua sponte declaration of a mistrial over defendant's objection because of misconduct of defense counsel.

83 See, e.g., People v. Michael, 48 N.Y.2d 1, 394 N.E. 1134, 420 N.Y.S.2d 371 (1979). For more information on this case, see Plea By Fraiman To Alter Rebuke Denied by Court, N.Y. Times, Sept. 25, 1979, $\$$ B, at 1, col. 6; Fraiman Offered to Shift Holiday and Finish Trial, N.Y. Times, July 14, 1979, $\$$, at 21 , 
Examples of each type of case can be readily multiplied. All have a common theme: in none does double jeopardy policy have a role to play, although, of course, the result required under the manifest necessity test may coincide with that reached under a double jeopardy analysis.

\section{Mistrials Caused by Prosecutorial Error}

A different case is presented when a mistrial is declared without the defendant's consent because of prosecutorial error. ${ }^{84}$ As in other mistrial cases, resolution of the case may be framed simply in terms of whether a manifest necessity existed to terminate the trial. ${ }^{85}$ In these cases, however, the test has sufficient play in its joints to permit policy concerns to operate. ${ }^{86}$

Downum v. United States ${ }^{87}$ and Illinois v. Somerville ${ }^{88}$ are illustrative. In Downum, the jury was sworn, but trial had not otherwise begun, when the prosecutor discovered that one of his key witnesses was not present. ${ }^{89}$ The prosecutor's motion to discharge the jury was granted over defendant's objection, and the proceedings were begun again two days later.90 Retrial was barred by the Supreme Court. ${ }^{91}$ In Somerville, after the jury had been sworn, the prosecutor noticed a jurisdictional defect in the indictment that could not be waived or cured by amendment.92 Because any conviction obtained under the indictment would be reversed on appeal, the prosecutor's motion for a mistrial was granted over the defendant's objection. ${ }^{93}$ In this instance, termination was deemed col. 6; Behavior of 2 Judges Is Criticized As Court Reverses 3 Convictions, N.Y. Times, July $11,1979, \S \mathrm{A}$, at 1 , col. 1 .

84 In cases in which a mistrial has been granted at defendant's request because of prosecutorial error or misconduct, the manifest necessity test is not dispositive. Rather, according to dictum in Dinitz, the question is whether the prosecutor in bad faith "provoke[d]" the mistrial request "so as to afford the prosecution a more favorable opportunity to convict." United States v. Dinitz, 424 U.S. 600, 611 (1976) (quoting Downum v. United States, 372 U.S. 734, 736 (1963)). For a discussion of this category of cases, see text accompanying notes 104-10 infra.

85 See, e.g., Illinois v. Somerville, 410 U.S. 458, 469 (1973); United States v. Jorn, 400 U.S. 470,487 (1971); Downum v. United States, 372 U.S. 734, 736 (1963).

86 See also People v. Benton, 402 Mich. 47, 260 N.W.2d 77 (1977).

87372 U.S. 734 (1963).

88410 U.S. 458 (1973).

89372 U.S. at 735.

$90 \mathrm{Id}$.

91 Id. 738.

92410 U.S. at $459-60$.

93 Id. 
manifestly necessary, and the prosecutor was granted a second opportunity to convict. ${ }^{94}$

Yet whether the absence of a key prosecution witness or a defective indictment constitutes a manifest necessity to terminate the trial is open to debate. ${ }^{95}$ In Somerville, the Court made clear that the question of retrial turned on Green policies, ${ }^{96}$ particularly that of reducing the risk of unjust conviction. The Court, contrasting the ground for termination in Downum, stated that the Somerville error would not "lend itself to prosecutorial manipulation." ${ }^{27}$ It could not be used to abort a trial that is not going well and thus "allow the prosecution an opportunity to strengthen its case." 98 This concern is not one the Court takes lightly. As it said in Washington: "The prohibition against double jeopardy unquestionably 'forbids the prosecutor to use the first proceeding as a trial run of his case." " 80

While condemning this practice in Somerville, the Court permitted retrial after a mistrial due to a fatally defective indictment. ${ }^{100}$ In so doing, it subjected the accused to the risk that the prosecutor could strengthen his case as a result of his experience in the prior proceeding. Yet this danger, which exists whenever retrial occurs, was not deemed sufficient to compel disregard of the state's desire to avenge violations of its laws. The Court is distinguishing cases involving error that "lend[s] itself to prosecutorial manipulation," 101 in which retrial is barred because it would allow the state the forbidden "opportunity to strengthen its case," 102

94 Id. 459.

95 As the dissenters in Somerville pointed out, proceeding with the trial would not necessarily have been for naught; the defendant might have been acquitted, thus ending his confrontation with society once and for all. Id. 474-75 (White, J., dissenting).

Similarly, in Downum the Court cautioned that it was not saying that missing prosecution witnesses can never justify declaration of a mistrial. 372 U.S. at 737 .

${ }^{96}$ See text accompanying note 47 supra.

97410 U.S. at 464.

98 Id. 469.

There is nothing to suggest that the prosecutor in Downum deliberately failed to secure the presence of his witness. He did, apparently, knowing that his witness was not present, allow the jury to be impaneled and sworn, see Arizona v. Washington, 434 U.S. 497,508 n.24 (1978), but he did not permit opening statements to be made or any evidence to be presented.

99434 U.S. at 508 n.24 (quoting Note, Twice in Jeopardy, 75 YAr.E L.J. 262, $287-88(1965))$.

100 Downum, 410 U.S. at 459.

101 Somerville, 410 U.S. at 464.

102 Id. 469. 
from other mistrials in which retrial is permitted despite the fact that the prosecutor would appear to enjoy a similar opportunity.

The distinction rests in the relative threat posed by each type of case to the defendant's Green interest in minimizing the risk of unjust conviction. While all repeated prosecutions undermine the defendant's repose interest, the additional factor of a prosecutor determined to shore-up feared or demonstrated weaknesses in his case so skews the normal trial process that it unacceptably enhances the risk of unjust conviction. Because the circumstances of the mistrial in Somerville did not suggest that the prosecutor was seeking to terminate a trial he sensed was going badly ${ }^{103}$ or that he had any reason to believe that anything different should be done upon retrial, the Court saw no reason to stem the ongoing course of the criminal process. Whenever the prosecutor secures an opportunity to obtain new evidence, or simply to polish that which he already had in light of events at the first trial, for presentation to a different, perhaps more sympathetic jury, the defendant's Green interest in limiting the risk of unjust conviction becomes deserving of great respect and tips the scales against retrial.

A similar concern regarding the risk of unjust conviction can be seen in those cases involving a mistrial provoked by prosecutorial or judicial "overreaching;" 104 but granted on the defend-

103 The prosecutor in Somerville had no reason to doubt the strength of his case; there was no indication that any of his witnesses were missing and no evidence had yet been presented.

Indeed, the type of error in Somerville does not lend itself to manipulation because, unlike error that can be introduced once trial has begun, it exists from the outset without regard to how well or poorly the state's case is proceeding. Admittedly, the prosecution could benefit from deliberately building in such error-were it possible to do so-gaining a preview of defendant's case by using the first trial as an extraordinary discovery process and also a rehearsal of his own presentation. But because it would be difficult for the prosecution deliberately to secure a defective indictment, and any conviction obtained under such circumstances would be reversed on appeal, it is most unlikely that a prosecutor would so act. If he is determined to secure for himself the option of the forbidden "trial run," he will do so in circumstances that allow him to preserve any victory he might obtain the first time round. That is, while a prosecutor could deliberately build in error of the type in Somerville to gain some "tactical advantage" over the defendant, Arizona v. Washington, 434 U.S. 497, 508 (1978), the chance that he would do so at the cost of being unable to convict is minimal. The greater danger relates to error that can be introduced during trial when the prosecutor senses that his case is not going well so as to secure an opportunity to begin again.

Cf. Westen and Drubel, Toward A General Theory of Double Jeopardy, 1978 SuP. CT. REv. 81, 93 n.68 (built-in error in Somerville was not capable of manipulation because prosecutor brought it to attention of court before defendant's case had been presented).

104 United States v. Jorn, 400 U.S. 470, 485 n.12 (1971) (Harlan, J., plurality opinion). Mistrials provoked by prosecutorial "overreaching" were also recognized in dictum in United States v. Dinitz, 424 U.S. 600, 611 (1976). The Court has not yet decided a case involving a successful claim of overreaching. See Divans v. California, 434 U.S. 1303 (1977). 
ant's motion. As a general rule, there is no constitutional bar to retrial following a mistrial requested by the defendant: ${ }^{105}$ because he chose to terminate the first trial, the defendant cannot complain when he is retried. ${ }^{100}$ If the defendant is forced to request a mistrial because of official overreaching, however, retrial is barred.107

Precisely what type of prosecutorial or judicial misconduct constitutes "overreaching" has not yet been determined. ${ }^{108}$ The Court has expressed itself on the question only in dictum. ${ }^{100} \mathrm{Al}$ though it is not clear how broad this notion is, it at least embraces "governmental action intended to provoke mistrial requests ... 'so as to afford the prosecution a more favorable opportunity to convict the defendant." " 110 Here, as in other mistrial cases, the prosecutor may not utilize the first trial as a dry run. To permit him to do so would raise the specter of unjust conviction. The mere opportunity to improve his case the second time round is not decisive. It is instead that opportunity under circumstances in which the prosecutor either fears or knows his case is not going well and will, therefore, make an extraordinary effort to remedy the deficiency.

\section{Acquittals and Reversed Convictions}

Looking next at cases in which double jeopardy issues arise after entry of a verdict, the first to be examined are those in which

105 The manifest necessity test is not used in cases involving a mistrial declared on defendant's motion. United States v. Dinitz, 424 U.S. 600, 607 (1976).

106 The Court has rejected "traditional waiver concepts" as justification for permitting retrial where defendant requests termination of a trial "tainted by prejudicial judicial or prosecutorial error," emphasizing instead the fact that "the defendant retain[s] primary control over the course to be followed in the event of such error." United States v. Dinitz, 424 U.S. 600, 609 (1976) (footnote omitted). It is difficult to understand the difference between "waiver" and choosing a particular course of events in this context. Indeed, the concept of waiver would seem to explain the result not only in these cases, but also in those involving appellate reversal of conviction on grounds other than insufficiency of the evidence. See Comment, Double Jeopardy and Reprosecution After Mistrial: Is the Manifest Necessity Test Manifestly Necessary?, 69 Nw. U.L. REv. 887, 889 (1975); text accompanying notes 127-36 infra.

107 United States v. Jorn, 400 U.S. 470, 485 n.12 (1971) (Harlan, J., plurality opinion). See also United States v. Dinitz, 424 U.S. 600, 611 (1976).

103 See generally Comment, The Double Jeopardy Clause and Mistrials Granted on Defendant's Motion: What Kind of Prosecutorial Misconduct Precludes Reprosecution?, 18 DuQ. L. REv. 103 (1979); Comment, The Double Jeopardy Dilemma: Reprosecution After Mistrial on Defendant's Motion, 63 IowA L. Rev. 975 (1978).

109 See cases cited note 104 supra.

110 United States v. Dinitz, 424 U.S. 600, 611 (1975) (quoting Downum v. United States, 372 U.S. 734, 736 (1963)). 
the defendant was acquitted.111 As the Court has repeatedly stated: "The constitutional protection against double jeopardy unequivocally prohibits a second trial following an acquittal." 112

This absolute bar does not inexorably follow from the language in the fifth amendment.113 Although the bar to retrial fol-

$111 \mathrm{~A}$ defendant is acquitted when there is "a resolution [in the defendant's favor], correct or not, of some or all of the factual elements of the offense charged." United States v. Scott, 437 U.S. 82, 96-97 (1978) (quoting United States v. Martin Linen Supply Co., 430 U.S. 564, 571 (1977)).

In Green v. United States, 355 U.S. 184 (1957), the Court found an "implied acquittal" of first degree murder and held that retrial for first degree murder was barred where the defendant was charged with first degree murder, found guilty of second degree murder and his conviction reversed on appeal. For the significance of Green for the hung jury issue, see note 150 infra.

112 Arizona v. Washington, 434 U.S. 497, 503 (1978); accord, Burks v. United States, 437 U.S. I, 10-II (1978); Sanabria v. United States, 437 U.S. 54, 64 (1978); United States v. Scott, 437 U.S. 82, 88 (1978); United States v. Martin Linen Supply Co., 430 U.S. 564, 571 (1977); Fong Foo v. United States, 369 U.S. 141, 143 (1962); Green v. United States, 355 U.S. 184, 188 (1957); Kepner v. United States, 195 U.S. 100, 130 (1904); United States v. Ball, 163 U.S. 662, 669-70 (1896).

The Court has described this absolute bar on retrial following an acquittal as "[p]erhaps the most fundamental rule in the history of double jeopardy jurisprudence." United States v. Martin Linen Supply Co., 430 U.S. at 571.

113 The Supreme Court has properly eschewed a literal interpretation of the double jeopardy clause. A literal approach, barring retrial in all cases, inadequately accommodates society's interest in convicting those who have violated the law, and would be at odds with the defendant's right to a fair trial. For an instance in which a literal reading of the double jeopardy clause worked to the substantial detriment of the defendant, see United States v. Gibert, 25 F. Cas. 1287 (C.C.D. Mass. 1834) (No. 15,204), discussed in note 16 supra.

The legislative history shows that the double jeopardy clause was not intended to deprive the defendant of his ability to obtain a new trial following reversal of his conviction. See 1 AnNals of Cong. 781-82 (Gales \& Seaton eds. 1789). See generally J. Sigler, Double JEOPARDY 23-27 (1969). Of course, according the defendant the right to appeal an erroneous conviction is not inconsistent with barring retrial should his appeal be successful. The Court, however, rejected this result out of hand. See United States v. Ball, 163 U.S. 662 (1896).

Given the Court's conclusion that the defendant may be retried following reversal of his conviction, logic might suggest that retrial following appeal by the state would likewise be constitutionally permissible. In fact, a number of commentators have argued that logic and policy support affording the prosecutor the opportunity to appeal an erroneous acquittal. See note 118 infra.

The ALI draft provides for appeal by the state from an acquittal. ALI, adomistration of the Crmminal Law: Double Jeopardy $\$ 13$ (Off. Draft, 1935). It approves Justice Holmes's concept of "continuing jeopardy," Kepner v. United States, 195 U.S. 100, 134 (1904) (Holmes, J., dissenting), concluding that retrial following a successful appeal by the state is not a second prosecution for the same offense, but merely a continuation of the original trial.

This concept of continuing jeopardy-which would view a trial as continuing until a final judgment is entered-would justify retrial following an appeal by the state, as well as retrial following a hung jury. The Court, however, explicitly rejected it in Breed v. Jones, 421 U.S. 519, 534 (1975). But see United States v. Larkin, 605 F.2d 1360, 1368-69 (5th Cir. 1979). Holmes's concept has been used, nonetheless, to explain why the double jeopardy bar does not prevent retrial of a defendant who has secured reversal of a conviction. See Price v. Georgia, 398 U.S. $323,326-27$ ( 1970 ). 
lowing acquittal finds its historical roots in the common law plea of autrefois acquit, ${ }^{114}$ recent opinions emphasizing the finality of acquittals do so on the basis of the defendant's Green interests, ${ }^{115}$ and correctly so. These interests are heavily implicated in acquittals and to permit retrial would seriously undermine them: no jury could ever finally acquit, and sooner or later, through attrition, luck or otherwise, ${ }^{116}$ the prosecutor could in all probability obtain a conviction. It is no answer to say that no harm is done by the trial run because the prosecutor, by beefing up his case, does what every good lawyer would do and merely secures the conviction he should have obtained the first time round. The second trial is not simply what the first should have been. While there is always the danger that retrial of a financially and emotionally

114 In the seventeenth century Coke wrote of double jeopardy as an established part of the common law. $3 \mathrm{E}$. Coke, INstrrutes 210-13 (London 1644); $3 \mathrm{E}$. Cokse, Institutes 310-13 (6th ed. London 1680) (1st ed. London 1644). See also M. Hate, Pleas of the Chown 146-51 (London 1678). By the late eighteenth century, Blackstone observed that it was a "universal maxim" of English common law that "no man is to be brought into jeopardy of his life, more than once for the same offense." 4 W. Blackstone, Commentaries 329 (Oxford 1766). See also W. Hawkins, Pueas of the Crown 312 (7th ed. London 1795) (Ist ed. London 1716).

The common law prohibition against double jeopardy was embodied in the special pleas in bar that prevented further proceedings following a final verdict. The most important of those pleas were autrefois acquit and autrefois convict. See M. Hate, Pleas of the Crown 244-49 (London 1678); 4 W. Blackstone, Commentaries 329-30 (Oxford 1766). Coke also included the plea of former pardon, 3 E. CokE, InstrTutes 213-14 (6th ed. London 1680) (Ist ed. London 1644), and Chitty included the plea of attainder, $1 \mathrm{~J}$. Chirty, A Practicar. Treatuse on the Crmmnal Law 463-67 (Phila. 1819). See also Comment, Twice in Jeopardy, 75 YarE L.J. 262, 262 n.I (1965). The pleas primarily reflected a res judicata policy of finality: a person could not be retried if he had been previously acquitted or convicted of the same offense. If, however, criminal proceedings for any reason terminated before a verdict, the defendant could not complain. The only defense against reprosecution at common law was by special plea; because no verdict had been rendered, neither autrefois acquit nor autrefois convict was available.

For the history of double jeopardy generally, see M. Frusdrand, Doubre Jeopardy 5-15 (1969); J. Sigler, Double Jeopardy 1-37 (1969).

115 See, e.g., United States v. Scott, 437 U.S. 82, 91 (1978). Compare this somewhat dubious rationale for the absolute bar on retrial following an acquittal:

The public interest in the finality of criminal judgments is so strong that an acquitted defendant may not be retried even though "the acquittal was based upon an egregiously erroneous foundation." ... If the innocence of the accused has been confirmed by a final judgment, the Constitution conclusively presumes that a second trial would be unfair.

Arizona v. Washington, 434 U.S. 497, 503 (1978) (citation omitted). Quaere: in what sense does an erroneous acquittal confirm the innocence of the accused?

116 This danger has long been recognized: "[A]llow this right to the Solicitor, and the prosecutor is prepared, by the first trial, to meet all the points of the prisoner's defence, and even to shape his own testimony to conviction. This would be making the Court hold out every inducement to perjury, and subornation of perjury ...." State v. M'Kee, 17 S.C.L. (1 Bail.) 651, 655 (1830). 
exhausted defendant will produce an improper result, the risk of unjust conviction becomes intolerable when we add the factor of a revanchist prosecutor determined to win his case.

The solicitude with which the Court regards the defendant's Green interests is further illustrated by the Court's application of this absolute proscription on retrial following an acquittal ${ }^{117}$ to cases in which it is conceded that the acquittal was erroneous.118 Those cases are quite correct. For even where it might be argued plausibly that the defendant was erroneously acquitted, retrial would pose an unacceptably high risk of unjust conviction.

Suppose, for example, an acquittal is tainted with judicial error favoring the defendant on matters such as the charge to the jury, the admissibility of evidence or, more dramatically, a directed verdict of acquittal. With respect to his guilt or innocence, the

117 A corollary of this absolute bar on retrial is the rule that denies the state the opportunity to appeal from an acquittal. United States v. Scott, 437 U.S. 82, 91 (1978). An exception is recognized for appeal from a judgment of acquittal entered by the trial court following a jury verdict of guilty. No retrial would be required because the original verdict can be reinstated. See United States v. Wilson, 420 U.S. 332 (1975); cf. United States v. Martin Linen Supply Co., 430 U.S. 564 (1977) (no appeal from directed verdict of acquittal following hung jury). For a discussion of permitting the state to appeal from an erroneous acquittal, see note 118 infra.

118 See, e.g., Sanabria v. United States, 437 U.S. 54 (1978); Fong Foo v. United States, 369 U.S. 141 (1962).

The rule in England has not always been so. Hale noted that a plea of au trefois acquit barred a subsequent indictment on the same felony "unless [the] appeal be erroneous in substance." M. Hare, PLeas of the Crown 206 (London 1678).

A number of commentators have argued that the state should be permitted to appeal erroneous acquittals in some circumstances. See ALI, ADminxstratton of the Crimmal Latv: Double Jeopardy $\$ 13$ (Off. Draft, 1935); Comley, Former Jeopardy, 35 Yaxe L.J. 674 (1926); Kirchheimer, The Act, The Offense and Double Jeopardy, 58 YALE L.J. 513, 542-43 (1949); Mayers \& Yarbrough, Bis Vexari: New Trials and Successive Prosecutions, 74 Harv. L. REv. 1, 13-16 (1960); Comment, Statutory Implementation of Double Jeopardy Clauses: New Life for a Moribund Constitutional Guarantee, 65 YALE L.J. 339, 362-63 (1956). See also Kepner v. United States, 195 U.S. 100, 134-37 (1904) (Holmes, J., dissenting).

The Supreme Court has held that such appeals do not violate the fourteenth amendment. Palko v. Connecticut, 302 U.S. 319 (1957). After Palko, however, the Court decided that the double jeopardy clause of the fifth amendment is applicable to the states. Benton v. Maryland, 395 U.S. 784 (1969). Prior to Benton, three states, Connecticut, Vermont and Wisconsin, had statutes permitting the prosecutor to appeal from an acquittal for errors of law. All three upheld their statutes as a matter of state law. See State v. Lee, 65 Conn. 265, 30 A. 1110 (1894) (common law double jeopardy); State v. Felch, 92 vt. 477, 104 A. 23 (1918) (common law double jeopardy); State v. Witte, 243 Wis. 423, 10 N.W.2d 117 (1943) (state constitution); cf. State v. Evjue, 254 Wis. 581, 37 N.W.2d 50 (1949) (state cannot appeal trial court determination of not guilty if the trial was free from procedural errors of law even though verdict is clearly contrary to weight of evidence). The constitutionality of such appeals under the fifth amendment seems dubious at best. 
defendant is in approximately the same position he was before trial. The state's interest in prosecuting him is as significant as it was then and his desire to be sent home of no greater moment than that of any defendant whose trial has not yet begun. Retrial following such an acquittal is not, however, constitutionally permissible, no matter how grievous the alleged error. For, as the Court has recognized, even a defendant whose acquittal could be reversed on appeal has a substantial interest in avoiding retrial lest he be unjustly convicted the second time round: "To permit a second trial after an acquittal, however mistaken the acquittal may have been, would present an unacceptably high risk that the Government, with its vastly superior resources, might wear down the defendant so that 'even though innocent he may be found guilty.' " 118 Not only would the defendant be worn down by the strain of one complete trial, but he would also have to face a prosecutor determined not to lose again. To be sure, the acquittal was tainted by judicial rather than prosecutorial error, but this may be of small comfort to the prosecutor. The prosecutor can never be certain that the judicial error was the sole cause of the verdict. For example, if the error lay in a directed verdict of acquittal, the prosecutor may nevertheless interpret the incorrect direction of acquittal as suggesting that his case could be stronger. He will scrutinize both his own and the defendant's case in preparation for a second round. The grant of this extraordinary opportunity, so at variance with the normal trial process, and the earnestness with which the prosecutor can be expected to seek to exploit it, operate to "present an unacceptably high risk" 120 that an innocent defendant may be convicted.

Nor does the state's interest in convicting the guilty compel a contrary result. Although trials are an imperfect method of arriving at truth, there are worse ones. ${ }^{121}$ The risk that some trials will be tainted with error and some scoundrels will go free is a tolerable price to pay for protection of the defendant's Green interests. ${ }^{122}$

119 United States v. Scott, 437 U.S. 82, 91 (1978) (quoting Green v. United States, 355 U.S. 184, 188 (1957)).

120 United States v. Scoth, 437 U.S. at 91.

121 For example, trial by compurgation, battle or ordeal. See generally 1 W. Holdsworte, A History of ENGLISH LAW 305-1I (7th ed. rev. 1956); L. Levi, Origins of the Fifth AMendment 5-7 (1968); 2 F. Pollock \& F. MaItLAND, The History of ENGLish Law 598-601 (2d ed. 1898).

122 Although the prisoner, if unfortunately guilty, may escape punishment in consequence of the decision this day made in his favor, yet it should be remembered that the same decision may be a bulwark of safety to those who, more innocent, may become the subjects of persecution, and whose 
The concern that retrials would engender a spate of unjust convictions is a matter of considerable moment in acquittal cases and clearly overrides the state's relatively limited interest in pursuing the matter further. ${ }^{123}$

Before turning to the dismissal cases, one other full-trial situation, the reversed conviction, remains to be considered. If the defendant's conviction is reversed on appeal for insufficiency of the evidence, retrial is barred.124 If protection of the defendant's interests requires a limit to one trial when the jury acquits, a fortiori the same limitation should apply following a determination that the prosecutor has failed to put in enough evidence even to warrant submission of the case to the jury. ${ }^{125}$ As the Supreme Court has recently stated, this prohibition of "a second trial for the purpose of affording the prosecution another opportunity to supply evidence which it failed to muster in the first proceeding [is] central" to the double jeopardy bar on multiple prosecutions. ${ }^{126}$

conviction, if not procured on one trial, might be secured on a second or third, whether they were guilty or not.

In re Spier, 12 N.C. $329,331,1$ Dev. 491, 493 (1828).

123 Additionally, in the acquittal case, special deference is paid to the defendant's repose interest. Post-acquittal procedures to uncover trial error are generally prohibited. In United States v. Ball, 163 U.S. 662, 671 (1896), the Court stated that a verdict of acquittal not only precluded retrial, but also "could not be reviewed, on error or otherwise, without putting [the defendant] twice in jeopardy, and thereby violating the Constitution." But nearly eighty years later, the Court held that the government could appeal from a directed verdict of acquittal entered after the jury had returned a verdict of guilty. United States v. Wilson, 420 U.S. 332 (1975).

It might be argued under Wilson that an appeal by the state does not in and of itself violate double jeopardy. That is, as long as the defendant is not retried, his double jeopardy guarantee is not violated. Hence, an appeal not only would be permitted in cases in which retrial is unnecessary, but also would be available to any prosecutor who sought simply to demonstrate that defendant's acquittal was tainted with error. Such an appeal might, of course, be barred for other reasons, such as judicial economy.

On the other hand, Ball and Wilson, read together, can be fairly seen as barring an appeal in all cases in which retrial is constitutionally impermissible. This would appear to be the better view. Under the Criminal Appeals Act, 18 U.S.C. $\oint 3731$ (1976), the prosecutor in a federal case may not appeal a ruling favorable to the defendant if the double jeopardy clause proscribes further prosecution.

The Court has recognized that the double jeopardy clause protects against prolongation of the period during which the defendant is "stigmatized by an unresolved accusation of wrongdoing." Arizona v. Washington, 434 U.S. 497, 504 (1978) (citations omitted). The availability of a post-acquittal review would condemn all defendants to a continuing state of anxiety. Nor would such anxiety be unfounded. Few, if any, trials are totally error-free. Most of the acquitted could, without the prosecutor subjecting himself to charges of bad faith, be put to a substantial prolongation of their ordeal, at least through the slowly grinding mill of the appellate process.

124 Burks v. United States, 437 U.S. 1 (1978).

125 Id. 16.

126 Id. 11. 
More frequently, the defendant obtains a reversal of his conviction on grounds other than sufficiency of the evidence, and the prosecutor may retry him. ${ }^{127}$ This case is readily distinguishable from a reversal for insufficient evidence. ${ }^{128}$ In the insufficient evidence case, the prosecutor knows that he has failed to present sufficient evidence to sustain a conviction. A second trial would provide the opportunity for a revanchist prosecutor to remedy the defect in his proofs, an opportunity that the double jeopardy clause forbids.129 For the same reason, convictions reversed on grounds other than insufficiency of the evidence are distinguishable from the acquittal cases. Justice Rehnquist has stated that "to require a criminal defendant to stand trial again after he has successfully invoked a statutory right of appeal to upset his first conviction is not an act of governmental oppression of the sort against which the Double Jeopardy Clause intended to protect." ${ }^{130}$ This statement suggests, with justification, that the Green interests in this instance are subordinate to those of the state. The repose interests of defendants who have been convicted, albeit after imperfect trials, do not equate to those of defendants whose trials culminated in

127 United States v. Ball, 163 U.S. 662 (1896).

The Court has rejected as a rationale for this rule the view that jeopardy "continues" until defendant's conviction is final. See Breed v. Jones, 421 U.S. 519, 534 (1977). It has also refused to apply a traditional waiver analysis to determine whether retrial is barred following reversal of a conviction. See United States v. Dinitz, 424 U.S. 600, 609 n.11 (1976). See notes 106 \& 113 supra.

Permitting retrial following reversal of the defendant's conviction has been explained as "fairer to both the defendant and the Government" than raising the double jeopardy bar. United States v. Tateo, 377 U.S. 463, 466 (1964).

Corresponding to the right of an accused to be given a fair trial is the societal interest in punishing one whose guilt is clear after he has obtained such a trial. It would be a high price indeed for society to pay were every accused granted immunity from punishment because of any defect sufficient to constitute reversible error in the proceedings leading to conviction. From the standpoint of a defendant, it is at least doubtfil that appellate courts would be as zealous as they now are in protecting against the effects of improprieties at the trial or pretrial stage if they knew that reversal of a conviction would put the accused irrevocably beyond the reach of further prosecution. In reality, therefore, the practice of retrial serves defendants' rights as well as society's interest.

Id. See also United States v. Wilson, 420 U.S. 332,343 n.11 (1975).

Whether appellate courts would less sedulously guard defendant's due process right to a fair trial were retrial barred need not be determined. The "fairness" issue can be pretermitted because the reversed conviction cases can be explained on the basis of double jeopardy policies alone. See text accompanying notes 128-35 infra.

128 See text accompanying notes 125 \& 126 supra.

129 See Downum v. United States, 372 U.S. 734, 737 (1963); Cornero v. United States, 48 F.2d 69 (9th Cir. 1931); United States v. Watson, 28 F. Cas. 499 (C.C.S.D.N.Y. 1868) (No. 16,651); United States v. Shoemaker, 27 F. Cas. 1067 (C.C.D. III. 1840) (No. 16,279).

130 United States v. Scott, 437 U.S. 82, 91 (1978). 
acquittals. ${ }^{131}$ While any defendant who has been subjected to one trial has an understandable desire to avoid a second, one instinctively feels that the claim has greater force when pressed on behalf of those who are more likely to be innocent. When there has been no indication of factual innocence, ${ }^{132}$ the anxiety and expense of a second trial must be endured. ${ }^{133}$

Further, the prosecutor need not feel he certainly must do a better job on retrial. ${ }^{134}$ The rate of reconviction following reversal on appeal is sufficiently high to warrant an assumption that, unless key defense evidence has been excluded, reconviction is the likely result. ${ }^{ \pm 35}$ The prosecutor therefore has no special incentive to seek out a more favorable judge or jury, uncover additional evidence, polish the testimony of his witnesses, or otherwise strengthen his case, thereby enhancing the risk that an innocent defendant will be convicted. In sum, when reversal stems from grounds other than insufficiency of the evidence, neither Green interest justifies denying the state its opportunity to retry.

\section{Dismissals}

The dismissal cases further illustrate current double jeopardy policy. In United States $v$. Scott, ${ }^{136}$ the trial court granted the

131 See note 123 supra.

132 United States v. Scott, 437 U.S. 82, 94 (1978). A conviction reversed on grounds other than insufficiency of the evidence "implies nothing with respect to the guilt or innocence of the defendant." Burks v. United States, 437 U.S. 1, 15 (1978).

133 See note 119 supra \& accompanying text.

134 See Burks v. United States, 437 U.S. at 15-16.

135 Although no empirical studies have documented the conviction rate on retrial following successful appeal of conviction, the percentage is estimated to be quite high. Approximately $70 \%$ of all criminal cases tried before juries in the federal courts result in conviction. ADMINISTRATIVE OFFICE OF THE UNITED States Courts, Federal Offenders in the United States Distruct Courts 1971 , at $3,25-26$ (1971). Conversations with prosecutors and others in the criminal justice field suggest that of cases retried after successful appeal, the conviction rate is at least as high.

Many successfully appealed cases result in reconviction because defendant pleads guilty to a lesser included offense to avoid the burden of retrial. In addition, prosecutors will usually choose not to bring to trial those cases in which the prospects for reconviction seem dim due to circumstances such as the disappearance of witnesses or the destruction of evidence.

136437 U.S. 82 (1978). In Lee v. United States, 432 U.S. 23 (1977), the Court permitted retrial of the defendant after the trial court granted his motion to dismiss a defective indictment. Stating that this dismissal was the functional equivalent of a mistrial, id. 31, the Court concluded that because there was no prosecutorial or judicial overreaching, and because defendant retained control over the course of events, the holding of United States v. Dinitz, 424 U.S. 600 (1973), applied. Id. 33-35. For a discussion of Dinitz, see note 84 supra. But see Sana- 
defendant's motion to dismiss based on a claim of preindictment delay. ${ }^{137}$ In holding that the state could appeal the mid-trial ruling and that the defendant could be retried, ${ }^{138}$ the Supreme Court emphasized that the defendant "[sought] to have the trial terminated without any submission to either judge or jury as to his guilt or innocence." 139 Absent an indication of factual innocence, ${ }^{140}$ the prosecutor has no special incentive to do anything different the second time round. In those circumstances, the defendant's Green interests-especially the interest in minimizing the risk of unjust conviction ${ }^{141}$-are not sufficiently implicated to warrant denying vindication of the state's interest in convicting the guilty. ${ }^{142}$

In highlighting the importance of a factual determination, the Court contrasted Scott with two non-dismissal cases-Burks $v$. United States ${ }^{143}$ and United States $v$. Green. ${ }^{144}$ In Burks, ${ }^{145}$ the defendant's conviction was reversed for insufficient evidence.146 The Court barred retrial, characterizing the case as one involving "a failure of proof" ${ }^{147}$ with regard to a factual issue. ${ }^{148}$ In Green,

bria v. United States, 437 U.S. 54 (1978) (dismissal operated as an acquittal, and despite the trial court's error, retrial was barred).

137437 U.S. at 84.

138 Id. 85-87; see note 75 supra.

139437 U.S. at 101.

140 Whether demonstrated-as in an acquittal-or merely perceived as a fear of the prosecutor that his proofs will be insufficient to convict.

141437 U.S. at 101.

142 Id. 100. In Scott, the Court again demonstrated that the defendant's repose interest, see text following note 47 supra, deserves no special protection absent some indication of factual innocence, such as a failure of the state's proof. The Court explicitly stated that protection of the repose interest is not a "principle" that applies to "situations in which the defendant is responsible for the second prosecution." Scott, 437 U.S. at 95-96.

Cf. note 123 supra. See also United States v. Martin Linen Supply Co., 430 U.S. 564 (1977); United States v. Wilson, 420 U.S. 332 (1975).

143437 U.S. 1 (1978).

144355 U.S. 184 (1957).

145 See text accompanying notes $124 \& 125$ supra.

140437 U.S. at 16.

147 The "failure of proof" rationale for barring retrial rests on the danger of unjust conviction that would be posed by affording the prosecutor the opportunity to remedy the defects in his proofs. Where the prosecutor "enter[s] upon the trial of the case without sufficient evidence to convict" retrial is barred. Downum v. United States, 372 U.S. 734, 737 (1963) (quoting Cornero v. United States, 48 F.2d 69, 71 (9th Cir. 1931)). This rule obtains in cases in which the insufficiency is demonstrated by entry of a verdict of acquittal or an appellate reversal, see, e.g., Burks v. United States, 437 U.S. 1 (1978), and those in which the prosecutor merely fears his proofs will fail, see, e.g., Downum v. United States, 372 U.S. 734 (1963); Cornero v. United States, 48 F.2d 69 (9th Cir. 1931); United States v. Shoemaker, 27 F. Cas. 1067 (C.C.D. Ml. 1840) (No. 16,279). A fortiori it would appear that retrial should be barred after a hung jury; inability to agree to convict evidences the failure of the prosecutor to prove his case.

148 The issue in controversy was the defendant's sanity. 437 U.S. at 2-4. 
the Court found an "implicit acquittal" 148 on a first degree murder charge in a conviction for second degree. Retrial for first degree murder was barred because the question of the defendant's guilt was submitted to the jury which "was given a full opportunity to return a verdict and no extraordinary circumstances appeared which prevented it from doing so." 150 It is precisely this point-that the question of the defendant's factual guilt or innocence was actually submitted to the jury-that is the ground on which the Court distinguishes Scott from Green. In Scott, the defendant succeeded in keeping the question of guilt or innocence from the trier of fact. ${ }^{151}$

\section{CODA}

What conclusions may be drawn regarding double jeopardy policy from the preceding discussion? Clearly, the Supreme Court gives little weight to the defendant's repose interest. The emotional and pecuniary injury a defendant suffers simply as a result of being retried does not alone provoke great sympathy. Something more is required. And that additional factor is a prosecutor seeking a new trial in order to improve what he knows or suspects is a weak case. The defendant's interest in limiting the risk of unjust conviction then outweighs the state's interest in convicting the guilty.

An acquittal is a demonstrated failure of proof. Were retrial permitted, the prosecutor, having suffered one loss, would likely make heroic efforts to prevent another. Similarly, when the defendant's conviction is reversed for insufficiency of the evidence, the prosecutor knows that he has failed to present enough evidence to convict and will usually seek to retry the defendant only if he thinks he can remedy the deficiency. The risk of unjust conviction becomes unacceptably high, and retrial is barred.

Contrast the conviction reversed on grounds other than insufficient evidence. Retrial here poses the same threat to the defendant's repose interest as would retrial following either an acquittal or a reversal for insufficient evidence. Yet further proceedings are permitted because the critical factor-a prosecutor alerted to the need to supply better evidence in the second trialis missing.

149355 U.S. 184, 190 (1957).

150 Id. 191.

For the view that under Green an implied acquittal must be inferred from the jury's inability to reach a verdict, see Stream, supra note 78, pt. 3 , at 4 , col. 1 .

151 Scott, 437 U.S. at 99. 
The prosecutorial-error cases, Downum v. United States ${ }^{152}$ and Illinois $v$. Somerville, ${ }^{153}$ support this analysis. The error in Somerville-a defective indictment-does not suggest to the prosecutor that he need remedy defects in his proofs. Retrial does not present an unacceptably high risk of unjust conviction and is thus not barred. The error in Downum, on the other hand-absence of a key witness-bears directly on the prosecutor's ability to prove the defendant's guilt. Because retrial would give the prosecutor a chance to do better when he knows he must, the situation in Downum is not unlike that following an acquittal or a conviction reversed for insufficiency of the evidence. Accordingly, retrial is barred.

What result obtains when these double jeopardy policies are applied to the hung jury case? What weight do they suggest should be assigned to the defendant's Green interests? ${ }^{154}$ As will be demonstrated, the case for barring retrial following a hung jury is stronger than that in Downum and nearly as compelling as that in the acquittal and in the conviction reversed for insufficiency of the evidence.

In fact, the acquittal case, although scarcely the perfect analogue to the hung jury, is not that dissimilar. The belief that hung juries frequently result from the presence of a single stubbornly unreasonable member is not borne out by research. As Kalven and Zeisel have demonstrated, ${ }^{155}$ the hung jury tends initially to split fairly evenly, and only after a rather prolonged wearing-down process does the vote reduce to near-unanimity. ${ }^{156}$ Thus, deadlocks generally do not involve cases in which guilt is clear to all but the credulous or demented. ${ }^{157}$ This is not to sug-
152372 U.S. 734 (1963).
153410 U.S. 458 (1973).
154 See notes 46-52 supra \& accompanying text.
155 H. Kalven \& H. Zetsel, The Amertacan JuRy (1966).
156 Id. 462-63.

157 Some critics of the view expressed in this Article suggest that to bar retrial following a hung jury is to give one juror too much power-the power to acquit. As an Ohio court, waxing somewhat hyperbolic, put it: "But to allow . . . the ignorance, perversity, or even honest mistake, of a single juror to paralyze the administration of justice, and turn loose upon the community the most dangerous offenders ... would subvert the foundation principles upon which the criminal code is administered." Dobbins v. State, 14 Ohio St. 493, 501 (1863). Cases no doubt exist in which one juror refused to vote for conviction even though he thought the defendant was guilty. For example, in the bribery trial of Representative Daniel Flood of Pennsylvania, the jury split $11-1$ for conviction, the one refusing to convict because Flood, age seventy-five, was "too old." Juror Who Opposed Conviction of Flood Assailed by a Colleague, N.Y. Times, Feb. 5, 1979, $\$ 4$, at 8, col. 5 .

By the same token, however, a single juror can prevent an acquittal. See, for example, the trials of Huey Newton for the 1974 murder of a seventeen year-old 
gest that the jury's inability to agree establishes a reasonable doubt. ${ }^{158}$ That argument appears foreclosed by recent Supreme Court decisions upholding non-unanimous jury verdicts. ${ }^{159}$ But

prostitute in Oakland, California. The first jury hung 10-2 for acquittal; the second deadlocked at 11-1 for acquittal. 2d Mistrial Is Declared for Newton; Prosecutor to Seek Closing of Case, N.Y. Times, Sept. 26, 1979, at 23, col. 3. See also Stream, supra note 95 , pt. 1 , at 1 , col. 3 . Yet the holdout juror in such a case is rarely condemned.

158 One commentator has argued that permitting retrial after a hung jury violates the constitutional requirement that guilt be proved beyond a reasonable doubt. Failure of the jury to agree on a verdict establishes a reasonable doubt as to defendant's guilt; accordingly, a verdict of acquittal should be entered, raising the double jeopardy bar to retrial. See Silverstein, Double Jeopardy and Hung Juries: United States v. Castellanos, 5 Rut.-CAM. L.J. 218 (1974); Silverstein, Rebuttal: An Alternative Viewpoint on the Relationship of Unanimous Verdicts and Reasonable Doubt, 11 VAI. L. Rev. 29 (1976). But see note 150 infra.

159 Johnson v. Louisiana, 406 U.S. 356 (1972); Apodaca v. Oregon, 406 U.S. 404 (1972).

Essential to the argument that inability of the jury to agree establishes a reasonable doubt is the proposition that failure of even one juror to be convinced of defendant's guilt raises a reasonable doubt and, under In re Winship, 397 U.S. 358 (1970), precludes conviction. The Court rejected this position in Johnson and Apodaca, cases in which judgments of conviction entered on verdicts of 10-2 and 9-3 were upheld. Implicit in the Court's holding that non-unanimous verdicts are constitutional is the view that the reasonable doubt of as many as three jurors does not constitute a doubt sufficient to preclude conviction.

In dictum in Arizona v. Washington, the Court stated (without citation of any authority): "The argument that a jury's inability to agree establishes reasonable doubt as to the defendant's guilt, and therefore requires acquittal, has been uniformly rejected in this country." Arizona v. Washington, 434 U.S. 497, 509 (1978).

Given Johnson and Apodaca, it is tempting to play a numbers game to assuage the one-irrational-juror fear. See note 157 supra. In a jurisdiction requiring that the verdict be unanimous, if a twelve-person jury hangs 11-1, 10-2, or perhaps even 9-3 for conviction, the votes of the dissenting jurors for acquittal would not raise a reasonable doubt regarding guilt and would not, therefore, bar retrial. On the other hand, at some point the number of votes for acquittal would be sufficient to establish a reasonable doubt, thus barring reprosecution. Whether that number be identified as eight, seven, six, five or even four might seem to be an arbitrary choice. Common sense would support a claim that if half of the members of the jury are persuaded that the defendant is not guilty, there is doubt, neither insubstantial nor trivial, about his guilt.

In the six-person jury cases the Court has demonstrated its willingness to engage in such arbitrary line-drawing as a matter of constitutional law. In Ballew v. Georgia, 435 U.S. 223 (1978), the Court held that although six-person juries are constitutionally permissible, five-person juries are not. In drawing the line where it did, the Court relied heavily on social science research about the way juries perform their deliberative functions. Also, in Burch v. Louisiana, 44I U.S. 130 (1979), the Court, reversing a 5-1 conviction, held that a verdict of guilty returned by a six-person jury must be unanimous. The Court conceded the diffculty of distinguishing a vote of 5-I from a vote of $6-0$, and said simply "lines must be drawn somewhere." Id. 137.

There may be, however, a practical problem with the numbers game. The available social science research, although suggesting that juries hang because of doubt about the sufficiency of evidence, indicates that the initial vote of juries that ultimately hang is generally close, but the final vote is not likely to be. The usual pattern is a substantial dissent on the first ballot that gradually reduces in size as deliberations continue. On the final ballot, usually only one or two jurors are still dissenting. H. Kalven \& H. Zetser, The Amerxcan JURY 460-61 (1966). 
these cases do involve a group of defendants whose guilt is not apparent and who, in all probability, have a higher percent of innocents among them than do accuseds in general. ${ }^{160}$ Accordingly, even if the repose interest of this group is not worthy of the same respect as that of defendants who have been acquitted, we cannot disregard altogether the injury to their psychic and financial wellbeing that multiple trials inflict.

In all events, the repose interest does not stand alone, but exists in tandem with a concern about the risk of unjust conviction, a concern that is scarcely limited to the acquittal cases. ${ }^{161}$ This risk infiltrates the hung jury case. In this instance, in contrast to both the case of a conviction reversed on grounds other than insufficiency of the evidence and the case of a defective indictment, the prosecutor is unlikely to treat a second trial as a carbon of the first. Indeed, the chances that a different, more effective presentation will be attempted are even greater than in cases involving error subject to manipulation. There the prosecutor only suspects that his case may not lead to conviction. After a hung jury, he knows that it has not. In this regard, the hung jury case may be even closer to one terminating in acquittal than one involving prosecutorial efforts to abort a trial that has not yet gone to a jury. The use of one trial as a learning experience to be put to use in another varies so dramatically from the normal criminal process that it alone suggests limiting the prosecutor to one full and fair oppor-

The implications of that suggestion are obvious. If Kalven and Zeisel are correct in stating that juries seldom hang on a vote closer than 10-2 or $9-3$, barring retrial when the jury hangs $8-4$ or $7-5$ or $6-6$ for acquittal will have practically no impact.

${ }^{160}$ Some courts have expressed the view that inability of the jury to agree quickly on defendant's fate is itself indicative of innocence. See United States v. Dailey, 524 F.2d 911, 917 (8th Cir. 1975); Commonwealth v. Cook, 6 Serg. \& Rawl. 577, 597 ( Pa. 1822).

It is not surprising then to find that some early courts took the position that a hung jury is "strong evidence" of innocence and concluded that retrial following a hung jury should be barred:

[A]s they could not agree to convict, it is strong evidence of the party's innocence; and perhaps he could not be tried again with the same advantage to himself as then. Perhaps his witnesses are dead, or gone away, or their attendance not be procured, or some accident may prevent their attendance. We will not again put his life in jeopardy, more especially as it is very improbable we shall be able to possess him of the same advantages ....

State v. Garrigues, 2 N.C. 188, 189, 1 Hayw. 24I, 242 (1795). See also Ned v. State, 7 Port. 187, 216 (Ala. 1838).

101 See text accompanying notes 104-10 supra. Research has amply demonstrated that the risk of wrongful conviction is not fanciful. See generally $\mathrm{E}$. Borchard, Convicting the InNocent (1932); J. Frank \& B. Frank, Not GUILTY (1957). 
tunity to present his case.162 In fact, the likelihood of innocence of a defendant subjected to retrial may not be critical. In discussing the danger of prosecutorial manipulation, Somerville makes no mention of it. Still, the argument against retrial is more appealing when it deals with defendants more likely to be innocent. A prosecutorial attempt to manipulate a mistrial suggests that unless the state's case can be strengthened an unfavorable result lies ahead. This, in turn, may be considered some indication of the innocence of the defendant. In any event, the defendants in the hung jury cases are indeed more likely to be innocent than is the run-ofmine accused. ${ }^{163}$

In sum, retrial after a hung jury not only runs roughshod over the defendant's repose interest, but more significantly, subjects him to an unacceptable risk of unjust conviction. The probability that a significant number of innocents exist among those whose juries have deadlocked operates to blunt the argument that the state's interest in pursuing violators of its laws demands repeated opportunities at conviction lest the guilty run free and the populace become fearful and insomniac.

Thus, the argument for barring retrial after a hung jury has force. ${ }^{164}$ The full implications of its acceptance, however, must be understood. ${ }^{165}$ The validity of the thesis advanced here is depend-

162 Even if the first trial is not completed, a second prosecution may be grossly unfair. It increases the financial and emotional burden on the accused, prolongs the period in which he is stigmatized by an unresolved accusation of wrongdoing, and may even enhance the risk that an innocent defendant may be convicted. The danger of such unfairness to the defendant exists whenever a trial is aborted before it is completed. Consequently, as a general rule, the prosecutor is entitled to one, and only one, opportunity to require an accused to stand trial.

Arizona v. Washington, 434 U.S. 497, 503-05 (1978).

163 See text accompanying notes $155-60$ supra.

164 State courts, of course, could bar retrial following a hung jury under the double jeopardy provisions of their state constitutions even if the Supreme Court refuses to depart from its century-old rule. Recently, commentators have noted a willingness by state courts to provide defendants greater protection under state law than that accorded under the United States Constitution. See, e.g., Brennan, State Constitutions and the Protection of Individual Rights, 90 HARv. L. Rev. 489 (1977); Howard, State Courts and Constitutional Rights in the Day of the Burger Court, 62 VA. L. Rev. 873 (1976); Wilkes, More on the New Federalism in Criminal Procedure, $63 \mathrm{KY}$. L.J. 873 (1975); Wilkes, The New Federalism in Criminal Procedure: State Court Evasion of the Burger Court, $62 \mathrm{Kx}$. I.J. 421 (1974); Note, Stepping Into the Breach: Basing Defendants' Rights on State Rather than Federal Law, 15 AM. Crm. L. REv. 339 (1978). See generally, Y. KaMnsar, W. Lafave \& J. Israel, Modern Crumanal Procedure 2-5 (Supp. 1980).

165 Judges and commentators have expressed concern that barring retrial after a hung jury would increase the risk of coerced verdicts. See, e.g., Arizona v. Washington, 434 U.S. 497, 509-10 (1978); Morano, Historical Development of the Interrelationship of Unanimous Verdicts and Reasonable Doubt, 10 VAL. L. REv. 223 
ent upon a rejection of the doctrine of manifest necessity as the lodestar in mistrial cases. If this is done, and constitutionally based policies become determinative in the hung jury case, so must they in all other instances in which manifest necessity now forces particular results. All these cases would then be subject to a fresh evaluation ${ }^{168}$-a formidable task and one well beyond the scope of this Article. That an arduous piece of work remains to be done, however, is scant justification for repeating past errors. Double jeopardy is a constitutional doctrine, and, as such, its hoary common law antecedents should not from their graves control and distort its policies.

(1976). They fear that the trial judge, aware of the consequences of a hung jury, would unduly pressure the jury to reach a verdict rather than discharge them for inability to agree; this judicial reluctance to find that the jury is genuinely deadlocked would in turn exacerbate the coercive effect of hunger and fatigue on the jury.

This danger exists, of course, under the present rule. The trial judge would understandably prefer a verdict to disagreement, for if the jury fails to agree, the judge may have to hear the case again. Thus, simply as a matter of judicial economy, thero is some incentive for the court to pressure the jury to reach a verdict.

Should retrial following a hung jury be barred, however, this concern over economy of resources would be eliminated. Whether the jury acquitted, convicted or hung, there would be only one trial, unless the conviction were reversed on appeal. Because the effect of acquittal and deadlock would be the same, the assumption made by those who fear coerced verdicts must be either that trial judges prefer convictions or that jury deadlocks are too often the result of an irrational hold-out juror. Neither of those assumptions is self-evident; the latter has been shown to be unfounded. See note 150 supra.

166 Take, for example, the judicial error in declaring a mistrial in United States v. Jorn, 400 U.S. 470 (1971), in which the judge refused to permit certain witnesses to testify without first consulting an attorney. Despite assurances that they had been warned of their constitutional rights, the judge declared a mistrial to allow the witnesses to seek legal advice. The Supreme Court held that termination of the proceedings was not manifestly necessary and retrial was, therefore, barred. Once the lack of manifest necessity to terminate is no longer dispositive, however, the result presently reached is by no means a foregone conclusion. To treat such judicial exror as one would prosecutorial manipulation would evidence a belief in judicial impropriety. Cf. text at notes 33-34 supra (discussing excesses of judiciary in Stuart England). If, as might be expected, the Supreme Court is unwilling to base a decision on such grounds, the error-that-lends-itself-to-manipulation rationale would be inapposite. That failing, there seems no reason to afford great weight to the defendant's Green interests. Since we assume that the court is not manipulating a mistrial to give the prosecutor an opportunity to bolster a weak case, the risk of unjust conviction is not high.

Perhaps, however, in this instance, the state through its judicial officer may be deemed to have waived its right to a second trial. All this remains to be resolved.

Of course, in other instances the absence of the ancient manifest necessity test will not complicate matters much. Should, for example, continuation of the trial be physically impossible, the only reasonable conclusion-that retrial should be allowed-can readily be reached in another fashion. A simple recognition that the Green interests in such instances fall well short of those of the state will suffice to resolve the case.

In short, in evaluating the approach suggested in this Article, it is helpful not only to recognize the difficulties it creates, but also to avoid overstating them. 